\title{
Does patenting always help new firm survival? Understanding heterogeneity among exit routes
}

\author{
Masatoshi Kato (D) - Koichiro Onishi • Yuji Honjo
}

Accepted: 16 February 2021 / Published online: 25 May 2021

(C) The Author(s) 2021

\begin{abstract}
While patents are a valuable resource ensuring the competitive advantage of firms, there is limited evidence on the role of patents in the survival and exit strategies of new firms. To fill the gap in the literature, we examine whether the effects of patenting on new firm survival vary according to exit routes (bankruptcy, merger, and voluntary liquidation), while considering the endogeneity of patenting. We use a large-scale sample of new firms in the Japanese manufacturing and information services sectors for the period 2003-2013. The findings indicate that new firms with a higher stock of patents are less likely to go bankrupt. Conversely, new firms with a higher stock of patents are more likely to exit via merger. These findings are consistent, regardless of whether patent stock is measured based on the patent applications or granted patents. Furthermore, we provide evidence that new firms with a higher stock of granted patents are more likely to voluntarily liquidate their businesses.
\end{abstract}

Plain English Summary Can new firms enjoy a "patent premium" in terms of survival and exit outcomes?

\section{Kato $(\square)$}

School of Economics \& Research Center for Entrepreneurship, Kwansei Gakuin University, Hyogo, Japan

e-mail: mkato@kwansei.ac.jp

K. Onishi

School of Education, Waseda University, Tokyo, Japan

Y. Honjo

Faculty of Commerce, Chuo University, Tokyo, Japan
The findings of this study indicate that (1) patenting reduces the risk of bankruptcy, and (2) it increases the odds of exit via merger and voluntary liquidation. On the one hand, patenting ensures that new firms obtain competitive advantages, and thus, survive in the product market. On the other hand, it enables new firms to pursue successful exit strategies in the markets for ideas. This study concludes that new firms can enjoy a patent premium in terms of survival and exit outcomes. In promoting sustainable economic growth via entrepreneurship, policymakers need to shift their focus from creating more firms to creating innovative firms.

Keywords Patent $\cdot$ New firm survival Exit route Bankruptcy $\cdot$ Merger $\cdot$ Voluntary liquidation

JEL Classifications $\mathrm{L} 26 \cdot \mathrm{M} 13 \cdot \mathrm{O} 30$

\section{Introduction}

New innovative firms play a vital role in driving innovation and economic growth (Wennekers \& Thurik, 1999; Aghion et al., 2009; Block et al., 2013; Bos \& Stam, 2014), especially in modern entrepreneurial economies (Thurik et al., 2013). Meanwhile, it is well recognized that many firms exit some years after their foundation (Bartelsman et al., 2005) in different ways (Headd, 2003; Wennberg et al., 2010; Cefis \& Marsili, 2011, 2012; Coad, 2014). While some firms are forced to exit because of business failure, others close voluntarily for various reasons (Harada, 2007). Moreover, 
some firms exit via merger and acquisition (M\&A) as a desirable option (DeTienne \& Cardon, 2012; Cotei \& Farhat, 2018). While some scholars have addressed the exit route of new firms (e.g., Grilli et al., 2010; Cefis \& Marsili, 2011, 2012; Kato \& Honjo, 2015; Ponikvar et al., 2018), a research gap still exists in understanding the antecedents of new firm survival according to exit routes, such as bankruptcy, M\&A, and voluntary liquidation.

To date, numerous studies have highlighted the role of firms' innovative capabilities, a major source of competitive advantage in determining firm survival (Cefis \& Marsili, 2005, 2006; Colombelli et al., 2016). ${ }^{1}$ In practice, successful innovation enables firms to increase their probability of survival and has a stronger impact on new firms than on large, established ones (Rosenbusch et al., 2011). Using patents is a wellknown, significant innovation strategy to protect inventions and attract customers and external providers of capital (Audretsch et al., 2012; Holgersson, 2013; Zhou et al., 2016). The importance of the strategic use of intellectual property (IP) is increasing for technologybased firms to gain competitive advantage (Cho et al., 2018). However, acquiring and enforcing IP rights is costly, especially for small firms (Lanjouw \& Schankerman, 2004; Jensen \& Webster, 2006). Hence, it is still unknown whether patenting helps new firms survive or exit successfully.

To fill the gap, this study examines the role of patenting in determining new firm survival according to exit routes. We construct a large-scale sample of new firms in the Japanese manufacturing and information services sectors by matching a credit-reporting database with a Japanese patent database. In particular, we examine how the effects of patenting on new firm survival vary across exit routes (bankruptcy, merger, and voluntary liquidation), while taking into account the endogeneity of patenting. The major findings of this study are summarized as follows. First, new firms with a higher stock of patents are less likely to go bankrupt, regardless of whether patent stock is measured based on applied or granted patents. Second, new firms with a higher stock of patents are more likely to exit via merger, regardless of which patent measures are used. Third, new firms with a higher stock of granted patents are more likely to voluntarily close their businesses, while a

\footnotetext{
${ }^{1}$ For a survey of the relationship between innovation and performance, see Rosenbusch et al. (2011).
}

stock of patent applications is not significantly related to voluntary liquidation. This study contributes to a better understanding of the role of patenting in new firm survival by identifying heterogeneity in the effects of patenting among exit routes.

The remainder of this paper is organized as follows. Section 2 discusses the theoretical background of this study and develops hypotheses. Section 3 explains the empirical model used, including the estimation methods and variables. Section 4 describes the data used in the analysis and shows some descriptive statistics, while Section 5 presents the results and conducts robustness checks. Section 6 summarizes the findings and discusses the implications and limitations.

\section{Background and hypothesis development}

\subsection{Divergent exit routes}

To date, numerous studies have examined firm survival as post-entry performance (e.g., Audretsch, 1991; Mata \& Portugal, 1994; Audretsch \& Mahmood, 1995; Honjo, 2000). While many of these studies treated exits as homogenous events, recent research emphasizes divergent exit routes (e.g., Wennberg et al., 2010; Coad, 2014; Wennberg \& DeTienne, 2014). While some firms are forced to exit because of business failure, others plan their exits when their businesses are performing well. In practice, there are many exit options available to new firms.

Some studies distinguish between firm liquidation and sale as an exit route (e.g., Coad, 2014; Kato \& Honjo, 2015). Wennberg et al. (2010) indicated four types of exit: harvest liquidation, distress liquidation, harvest sale, and distress sale. Wennberg et al. (2010, p. 364) define harvest sale as the sale of a highperforming firm that continues operations after the entrepreneur exits as a majority owner, while a distress sale is the sale of a firm in financial straits. As M\&A exits, regarded as a typical form of firm sale, are desirable outcomes for some business owners, it is worth identifying which factors explain the M\&A exit outcomes (Cotei \& Farhat, 2018). Though distressed firms either decide to exit voluntarily or are forced into bankruptcy, voluntary liquidation fundamentally differs from bankruptcy (Balcaen et al., 2012). Coad (2014, p. 723) indicated that voluntary liquidation occurs when businesses fail to be viable economic entities or when the 
entrepreneurs consider other outside options. Voluntary liquidation can be characterized as "relatively unviable," usually occurring when a business is failing or otherwise seen as unviable. Meanwhile, Harada (2007) emphasized differences between economic-forced and noneconomic-forced exits (e.g., aging of a manager and despairing perception of further business) for small firms. Voluntary liquidation is an option irrespective of business performance (Wennberg et al., 2010; Coad, 2014). In these respects, there should be sharp differences between exit routes; however, without distinguishing between them, we may misinterpret the nature, determinants, and consequences of firm exit, including failure and non-failure outcomes.

Table 1 reviews empirical studies on exit routes. Schary's (1991) early work on exit routes, which examined different exit routes in the cotton textile industry, assumed that they should be inherently ordered as survival, merger, non-failure, and failure. Other studies examining firm exit have differentiated closure from M\&As (Fontana \& Nesta, 2009; Grilli et al., 2010; Cefis \& Marsili, 2011, 2012; Esteve-Pérez et al., 2010). Still others have grouped closures into bankruptcy and voluntary liquidation (Harhoff et al., 1998; Mata et al., 2007; Balcaen et al., 2012; Kato \& Honjo, 2015; Ponikvar et al., 2018). Among these exit studies, Fontana and Nesta (2009), Grilli et al. (2010), Wennberg et al. (2010), Balcaen et al. (2012), Cefis and Marsili (2012), Kato and Honjo (2015), and Honjo and Kato (2019) focused on new firms, showing sharp differences in the determinants of firm exit between the routes.

\subsection{Patenting and exit routes}

Based on the resource-based view of the firm (RBV), it is well recognized that patents are important resources that create a unique competitive advantage for firms (e.g., Hsu \& Ziedonis, 2013). Patents prevent competitors from utilizing the protected inventions for a certain period, so that firms can appropriate the returns from their investment in R\&D (e.g., Levin et al., 1987). Patenting can improve firms' competitive position, which results in a higher probability of survival (e.g., Cefis \& Marsili, 2005, 2006).

Not surprisingly, new firms that lack complementary assets, such as marketing channels and production facilities, often face difficulties in appropriating returns from their innovations (e.g., Teece, 1986; Colombo et al., 2006). For small, start-up ventures, patents may be a relatively effective means of appropriating $R \& D$ returns, in part because other means such as investment in complementary sales and service efforts may not be feasible (Levin et al., 1987, p. 797). Meanwhile, new firms may have various motives for patenting. Some firms use patents as "bargaining chips," which can improve their own position in negotiations with partners for technology access (e.g., Hall \& Ziedonis, 2001; Blind et al., 2009). New firms can earn greater profits through cooperation rather than competition with existing firms through licensing, joint venture, or acquisition (Veugelers \& Schneider, 2018). Negotiations about mergers, license contracts, or research cooperations depend mainly on how the partners evaluate the research efforts and results of their counterparts, which is mainly measured in the number of patents in the companies' portfolio (Blind et al., 2009, p.429). As the extreme case, the markets for "ideas" may operate through acquisitions of new innovative firms by established firms (Blonigen \& Taylor, 2000; Gans \& Stern, 2003). ${ }^{2}$ Such "division of innovative labor" is closely related to growing technology markets in hightech industries (Arora et al., 2001; Veugelers \& Schneider, 2018).

In reality, new innovative firms are often targeted by large established firms to acquire patents as a valuable resource. For example, Apple Inc. acquired NextVR Inc., a new three-dimensional virtual reality content transmission programming service provider, with a number of patent rights in this field, in a deal valued at approximately 100 million US dollars in May 2020. It is often argued that M\&A markets in Japan are not well developed (Honjo \& Nagaoka, 2018; Honjo, 2020). According to a report by Recof Data Corporation, a company collecting M\&A information in Japan, the number of M\&As involving Japanese firms increased twofold in two decades. Nowadays, new innovative firms are often merged or acquired by large established firms in Japan. For example, Soracom Inc., an IoToptimized cellular network operator founded in 2014, was acquired by KDDI Corporation (a huge cellular network operator) in 2017. According to databases compiled by Bureau van Dijk (Zephyr and Orbis Intellectual Property), this transaction includes the sale of patents

\footnotetext{
$\overline{{ }^{2} \text { Licensing-out }}$ using patents may be an effective strategy for new firms (Motohashi, 2008). Patenting firms can earn royalties by licensing out technologies to others; thus, they are less likely to go bankrupt. In this study, however, licensing-out is not analyzed explicitly, because it is not included in firm exit.
} 
Table 1 Review of empirical studies on distinct exit routes

\begin{tabular}{|c|c|c|c|c|}
\hline Author & Exit route & Major determinants & Sample & Method \\
\hline Balcaen et al. (2012) & $\mathrm{B}, \mathrm{M}, \mathrm{V}$ & $\begin{array}{l}\text { Firm (cash flow, leverage, debt, } \\
\text { age), Industry (dummies) }\end{array}$ & $\begin{array}{l}6118 \text { firms (firms less than } \\
5 \text { years old excluded), } \\
1998-2000, \text { Belgium. }\end{array}$ & Binomial nested logit \\
\hline Buehler et al. (2006) & $\mathrm{B}, \mathrm{M}(\mathrm{S})$ & $\begin{array}{l}\text { Firm (size, age), Region (dummies), } \\
\text { Industry (dummies) }\end{array}$ & $\begin{array}{l}\text { 54,750 firms } \\
\quad \text { (13.6 employees), } \\
\text { 1995-2000, } \\
\text { Switzerland. }\end{array}$ & Continuous-time duration \\
\hline Cefis and Marsili (2011) & $\mathrm{C}, \mathrm{M}(\mathrm{S})$ & $\begin{array}{l}\text { Firm (product and process } \\
\text { innovation, size, group affiliation, } \\
\text { patent application, } \\
\text { entrepreneurial-firm dummy), In- } \\
\text { dustry (low or high-tech dummy) }\end{array}$ & $\begin{array}{l}3203 \text { firms (young ones } \\
\text { within } 5 \text { years: } 8 \% \text { ), } \\
\text { 1996-2003, the } \\
\text { Netherlands. }\end{array}$ & Multinomial logit \\
\hline Cefis and Marsili (2012) & $\mathrm{C}, \mathrm{M}, \mathrm{R}(\mathrm{S})$ & $\begin{array}{l}\text { Firm (product and process } \\
\text { innovation, age, size), Industry } \\
\text { (Pavitt's categories) }\end{array}$ & $\begin{array}{l}3275 \text { firms ( } 118.2 \\
\text { employees, } 28.7 \text { years), } \\
\text { 1996-2003, the } \\
\text { Netherlands. }\end{array}$ & $\begin{array}{l}\text { Multinomial logit } \\
\text { and cloglog. }\end{array}$ \\
\hline Cotei and Farhat (2018) & $\mathrm{M}(\mathrm{S})$ & $\begin{array}{l}\text { Founder (education, work } \\
\text { experience, gender), Firm } \\
\text { (positive employment growth, } \\
\text { serial entrepreneur, R\&D, dummy } \\
\text { for patent, trademark or } \\
\text { copyright), Industry (dummies) }\end{array}$ & $\begin{array}{l}3140 \text { firms (created in } \\
\text { 2004), 2005-2011, } \\
\text { the USA. }\end{array}$ & Multinomial logit \\
\hline Esteve-Pérez et al. (2010) & $\mathrm{C}, \mathrm{M}(\mathrm{S})$ & $\begin{array}{l}\text { Firm (size, age, labor productivity, } \\
\text { price-cost margins, R\&D, } \\
\text { advertising), Industry (low, medi- } \\
\text { um or high-tech dummy) }\end{array}$ & $\begin{array}{l}2998 \text { firms ( } 257.5 \\
\text { employees, } 23.9 \text { years), } \\
\text { 1990-2000, Spain. }\end{array}$ & Continuous-time duration \\
\hline Fontana and Nesta (2009) & $\mathrm{C}, \mathrm{M}(\mathrm{S})$ & $\begin{array}{l}\text { Firm (technology frontier, R\&D } \\
\text { intensity, size, age) }\end{array}$ & $\begin{array}{l}121 \text { firms (470-480 } \\
\text { employees), } \\
\text { 1990-2005, worldwide } \\
\text { LAN switching } \\
\text { industry. }\end{array}$ & $\begin{array}{l}\text { Multinomial logit and } \\
\text { cloglog }\end{array}$ \\
\hline Grilli et al. (2010) & $\mathrm{C}, \mathrm{M}(\mathrm{S})$ & Firm (size, age), Industry (dummies) & $\begin{array}{l}\text { 13,574 firms ( } 1 \text { or } 2 \\
\text { employees, } 0 \text { to } 13 \\
\text { years), } 1983-2006 \\
\text { Italy. }\end{array}$ & $\begin{array}{l}\text { Continuous and } \\
\text { discrete-time } \\
\text { duration (cloglog) }\end{array}$ \\
\hline Harhoff et al. (1998) & $\mathrm{B}, \mathrm{V}(\mathrm{S})$ & $\begin{array}{l}\text { Firm (size, ownership, } \\
\text { diversification, legal status), } \\
\text { Industry (dummies) }\end{array}$ & $\begin{array}{l}\text { 10,902 firms ( } 276 \\
\text { employees, } 19 \text { years), } \\
\text { 1989-1994, West } \\
\text { Germany. }\end{array}$ & Continuous-time duration \\
\hline Honjo and Kato (2019) & $\mathrm{B}, \mathrm{M}(\mathrm{S})$ & $\begin{array}{l}\text { Firm (initial debt finance (size/ratio), } \\
\text { initial equity finance (size/ratio), } \\
\text { dummy for minimum capital } \\
\text { requirement regulation), Industry } \\
\text { (dummies) }\end{array}$ & $\begin{array}{l}\text { 16,185 firms (joint-stock } \\
\text { companies, less than } \\
100 \text { employees), } \\
\text { 1995-2011, Japan }\end{array}$ & Continuous-time duration \\
\hline Kato and Honjo (2015) & $\mathrm{B}, \mathrm{M}, \mathrm{V}(\mathrm{S})$ & $\begin{array}{l}\text { Founder (educational level/field, } \\
\text { age, gender), firm (paid-in capital, } \\
\text { age, legal status), Region } \\
\text { (unemployment rate), Industry } \\
\text { (HHI, growth, capital intensity, } \\
\text { low- vs. high-tech sector) }\end{array}$ & $\begin{array}{l}7868 \text { firms (less than } 100 \\
\text { employees, } 0 \text { to } 12 \\
\text { years), 1997-2004, } \\
\text { Japan. }\end{array}$ & $\begin{array}{l}\text { cloglog and } \\
\text { random-effects cloglog }\end{array}$ \\
\hline Mata et al. (2007) & $\mathrm{B}, \mathrm{V}(\mathrm{S})$ & $\begin{array}{l}\text { Firm (size, age, debt, bank } \\
\text { relationship, foreign ownership, } \\
\text { worker's wages, worker's }\end{array}$ & $\begin{array}{l}\text { 413,586 observations } \\
\quad \text { (14.8 years), } \\
\text { 1995-2000, Portugal. }\end{array}$ & Multinomial logit \\
\hline
\end{tabular}


Table 1 (continued)

\begin{tabular}{|c|c|c|c|c|}
\hline Author & Exit route & Major determinants & Sample & Method \\
\hline & & $\begin{array}{l}\text { Firm (financial conditions, size, age, } \\
\text { labor productivity, fixed asset } \\
\text { ratio), region (dummies), } \\
\text { Industry (dummies) }\end{array}$ & $\begin{array}{l}\text { 55,810 firms ( } 7.8 \\
\text { employees, } 10.2 \text { years), } \\
\text { 2006-2012, Slovenia. }\end{array}$ & \\
\hline Schary (1991) & $\mathrm{B}, \mathrm{M}, \mathrm{V}(\mathrm{S})$ & $\begin{array}{l}\text { Firm (debt, cash flow, other } \\
\text { financial characteristics) }\end{array}$ & $\begin{array}{l}61 \text { firms, } 1924-1940, \text { New } \\
\text { England textile } \\
\text { industry. }\end{array}$ & $\begin{array}{l}\text { Ordered logit and } \\
\text { multinomial logit }\end{array}$ \\
\hline $\begin{array}{l}\text { Wagner and } \\
\text { Cockburn (2010) }\end{array}$ & $\mathrm{D}, \mathrm{M}(\mathrm{S})$ & $\begin{array}{l}\text { Firm (age at IPO, size, total assets, } \\
\text { patent application, patent } \\
\text { citation), Industry (dummies) }\end{array}$ & $\begin{array}{l}356 \text { firms, }(5.9 \text { years }) \\
\text { 1998-2005, US } \\
\text { Internet-related indus- } \\
\text { tries. }\end{array}$ & Continuous-time duration \\
\hline Wennberg et al. (2010) & $\begin{array}{l}\text { Harvest/distress } \\
\text { liquidation } \\
\text { and sale, }(\mathrm{S})\end{array}$ & $\begin{array}{l}\text { Founder (Entrepreneurial/industry } \\
\text { experience, education, gender, } \\
\text { outside job, age), Firm (size, } \\
\text { ownership by the parent firm, } \\
\text { reinvestment), Industry } \\
\text { (dummies) }\end{array}$ & $\begin{array}{l}1735 \text { firms ( } 3 \text { employees, } \\
4.5 \text { years), 1995-2002, } \\
\text { Sweden. }\end{array}$ & Multinomial logit \\
\hline
\end{tabular}

Note:(1) $B$ bankruptcy, $M$ mergers and/or acquisitions, $V$ voluntary liquidation, $C$ closure, $R$ restructuring, $D$ divestiture, $S$ survival. (2) $\mathrm{S}$ in parentheses - (S) - means that the base outcome of the estimated model is "survival." (3) Firm, Industry, and Region indicate firm-, industry-, and region-specific variables, respectively. (4) In the fourth column ("Sample"), the sample average in firm size (number of employees) and/or firm age (years after start-up/foundation) are presented in parentheses

held by Soracom with 18 patent families at the time of the acquisition's announcement. Because of increasing attention to acquiring patents, it would be worthwhile investigating whether patents trigger M\&As in the markets for ideas.

Table 2 shows a review of previous studies on the effect of patenting on firms' exit routes. Among these studies, Wagner and Cockburn (2010) showed that patent applications generally reduce the probability of exit for Internet-related IPO firms listed in the NASDAQ market. They distinguished between the exit routes of merger and delisting, and found that patent applications have a significantly negative effect on exit via merger but no significant effect on delisting. In contrast, Wagner and Cockburn (2010) showed that patents with higher forward citations increased the probability of exit via merger. Cefis and Marsili (2011) examined whether patenting affects exit via closure and M\&A for young firms in the Netherlands; they showed that patent applications (measured as a dummy) decrease the probability of exit via M\&A but did not significantly affect the probability of closure. Using data from the Kauffman Firm Survey conducted in the USA, Cotei and Farhat (2018) found that young firms with IP rights, including patents and trademarks, are more likely to become targets for M\&A.
Until now, however, there is limited evidence on the effects of patenting on exit routes. To the best of our knowledge, there are no studies on the effects of patenting while considering its endogeneity. In addition, previous studies do not distinguish between bankruptcy (failure) and other types of closure (e.g., voluntary liquidation). In this study, we examine the effects of patenting on firms' exit by distinguishing between bankruptcy, merger, and voluntary liquidation, while considering the endogeneity of patenting.

\subsection{Hypothesis development}

Based on the above arguments, we develop our hypotheses on the effects of patenting on exit routes (bankruptcy, merger, and voluntary liquidation). ${ }^{3}$ Drawing on the $\mathrm{RBV}$, we consider alternative commercialization strategies using patents: competitive strategy in product markets and cooperative strategy with partners in markets for "ideas."

\footnotetext{
${ }^{3}$ In this study, we focus on firm exit and do not include acquisitions in our empirical analysis. With respect to acquisition cases, an acquiring firm and an acquired firm are regarded as surviving firms because neither firm disappears, although ownership is transferred.
} 
Table 2 Review of empirical studies on the relationship between patenting and exit

\begin{tabular}{|c|c|c|c|}
\hline Author & Patent measure & Major finding & Sample \\
\hline Buddelmeyer et al. (2010) & $\begin{array}{l}\text { (1) Patent application (2-year } \\
\text { lagged), (2) patent stock } \\
\text { (aggregates of number } \\
\text { of years in-force) }\end{array}$ & $\begin{array}{l}\text { (1) Positive on exit, } \\
\text { (2) negative on exit }\end{array}$ & $\begin{array}{l}\text { 299,038 firms (all companies } \\
\text { registered), 1997-2003, } \\
\text { Australia }\end{array}$ \\
\hline Cefis and Marsili (2011) & Patent application (dummy) & $\begin{array}{l}\text { Negative on exit via M\&A, } \\
\text { insignificant for closure }\end{array}$ & $\begin{array}{l}3203 \text { firms (young ones } \\
\text { within } 5 \text { years: } 8 \% \text { ), } \\
\text { 1996-2003, } \\
\text { the Netherlands }\end{array}$ \\
\hline Colombelli et al. (2013) & Patent application stock & Positive on survival & $\begin{array}{l}\text { 74,862 manufacturing firms } \\
\text { (firms created by 2001), } \\
\text { 2001-2011, France }\end{array}$ \\
\hline Cotei and Farhat (2018) & $\begin{array}{l}\text { IP rights (dummy for patent, } \\
\text { trademark, or copyright) }\end{array}$ & Positive on exit via M\&A & $\begin{array}{l}3140 \text { firms (created in 2004), } \\
2005-2011 \text {, the US }\end{array}$ \\
\hline $\begin{array}{l}\text { Helmers and } \\
\text { Rogers (2010) }\end{array}$ & Patent application (dummy) & Negative on exit & $\begin{array}{l}131,325 \text { firms, (limited } \\
\text { companies incorporated in } \\
\text { 2001), 2001-2005, UK }\end{array}$ \\
\hline Levitas et al. (2006) & $\begin{array}{l}\text { (1) Average citation ratio (\# } \\
\text { citations adjusted by the } \\
\text { application year and } \\
\text { patent class), (2) patent } \\
\text { activity (dummy) }\end{array}$ & $\begin{array}{l}\text { (1) Negative on exit, } \\
\text { (2) insignificant }\end{array}$ & $\begin{array}{l}295 \text { firms (the number of } \\
\text { employees is } \\
\text { approximately 500), } \\
\text { integrated circuit industry }\end{array}$ \\
\hline $\begin{array}{l}\text { Wagner and } \\
\text { Cockburn (2010) }\end{array}$ & $\begin{array}{l}\text { (1) Patent application } \\
\text { (dummy), (2) \# of US } \\
\text { patent application, } \\
\text { (3) \# patents w/more than } \\
6 \text { cites }\end{array}$ & $\begin{array}{l}\text { (1) Negative on pooled exit, } \\
\text { merger, and delisted, (2) negative } \\
\text { on pooled exit and merger, } \\
\text { insignificant on delisted, } \\
\text { (3) positive on exit via merger }\end{array}$ & $\begin{array}{l}356 \text { firms (5.9 years), } \\
\text { 1998-2005, US } \\
\text { Internet-related industries }\end{array}$ \\
\hline
\end{tabular}

Firms need to secure valuable resources, such as technological knowledge, when competing in product markets, thereby gaining competitive advantage (Wernerfelt, 1984; Barney, 1991). Especially for new firms, patents are an essential resource to protect inventions and attract customers and external providers of capital (Wagner \& Cockburn, 2010; Cefis \& Marsili, 2011; Audretsch et al., 2012; Holgersson, 2013; Zhou et al., 2016). In addition, patenting can be an indication of a firm's growth potential to external stakeholders (Holgersson, 2013; Cotei \& Farhat, 2018). Patenting is widely regarded as entrepreneurs' commitment to developing their innovative ideas (Cefis \& Marsili, 2011). Entrepreneurs without growth ambitions are unwilling to patent inventions despite having developed ideas, since it takes time and fees to apply and request substantial examination from patent offices. Under information asymmetry, patenting apprises potential lenders and investors, including venture capitalists, of the firm's technological capabilities (Hsu \& Ziedonis, 2008; Audretsch et al., 2012; Conti et al., 2013; Hoenig
\& Henkel, 2015; Hottenrott et al., 2016; Veugelers \& Schneider, 2018). ${ }^{4}$ Therefore, new firms with patents are valorized positively by external providers of capital (Zhou et al., 2016). Not only current investment in intangible assets but also previous intangible stock may affect new firm survival, since firms with a higher stock of patents have greater revenue potential (Buddelmeyer et al., 2010). As a result, firms can make commercial transactions feasible through more patents in product markets, which may ensure their competitive advantage, thereby reducing their probability of bankruptcy. For these reasons, we postulate the following hypothesis.

Hypothesis 1: New firms with a higher stock of patents are less likely to go bankrupt.

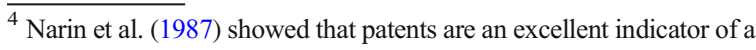
firm's overall technological strength.
} 
While some new firms may choose to compete with existing rivals in product markets, others may intend to use their patents as a tool to negotiate with partners in markets for "ideas" (Gans \& Stern, 2003). The patents held by small technologyoriented firms are their most marketable assets, providing something tangible to offer when they sell out later (Levin et al., 1987, p. 797). ${ }^{5}$ Generally, firms with patents, especially high-quality ones, become more attractive targets for M\&A because of the market value of their ideas (Wagner \& Cockburn, 2010). Scholars have argued that some patentees file for patents simply to improve their chances of being acquired (Graham \& Sichelman, 2008). Established firms typically pay high premiums to acquire high-potential start-ups that could result in substantial rewards for founders (Cotei \& Farhat, 2018). Meanwhile, the patent portfolio is an important aspect in the due diligence for M\&A (Breitzman \& Thomas, 2002). Firms' larger portfolio in terms of the number of patents puts the firms in a better bargaining position in negotiations (Blind et al., 2009; Noel \& Schankerman, 2013). Therefore, we postulate the following hypothesis.

Hypothesis 2: New firms with a higher stock of patents are more likely to exit via merger.

In the markets for ideas, new patenting firms can also sell their patent rights to other organizations and thus cash out their inventions, even if they cannot find appropriate partners for merger. Voluntary liquidation can generate higher sales proceeds than a merger, if multiple acquirers can redeploy the assets into higher-valued uses than what a single acquirer can possibly achieve (Kim \& Schatzberg, 1987). ${ }^{6}$ The probability of voluntary liquidation is higher when the expected liquidation value is higher, as well as when the expected M\&A value is lower than the expected liquidation value (Balcaen et al., 2012). New firms with more patents may have an option to close their businesses with

\footnotetext{
${ }^{5}$ Jensen and Webster (2006) presented evidence that smaller firms have a higher rate of IP usage, suggesting that patenting is an important strategy for small firms.

${ }^{6}$ Serrano and Ziedonis (2019) showed evidence that most patents from failed start-ups are sold quickly, and remain alive through renewal fee payment long after the closure of these start-ups.
}

solvency by holding patents as intangible assets or selling them out, and they can expect higher liquidation value. Based on these arguments, we postulate the following hypothesis.

Hypothesis 3: New firms with a higher stock of patents are more likely to exit voluntarily.

To test the above three hypotheses, in the following sections, we present the model and data used in the empirical analyses.

\section{Method}

\subsection{Empirical model}

We estimate the effect of patenting on the survival of new firms according to exit route. As shown in Table 1, while some empirical studies have used the continuous-time model to examine the duration of firm survival according to exit route (e.g., Buehler et al., 2006; Esteve-Pérez et al., 2010; Honjo \& Kato, 2019), others have used the discrete-time duration model (e.g., Fontana \& Nesta, 2009; Cefis \& Marsili, 2011, 2012; Kato \& Honjo, 2015). As the timing of survival and exit is observable only at the year level, we use the discrete-time duration model following the previous studies.

We classify exits into three routes: bankruptcy, merger, and voluntary liquidation. Let $T_{i j}$ denote a discrete-time random variable, which represents the period when firm $i$ exits via route $j(=1, \ldots, m)$. To model the transition from survival to exit, we define a hazard function $h_{i j}(t)$, which represents the conditional probability of a transition to route $j$ between periods $t$ and $t+1$ for surviving firm $i$. Using a probit model, the hazard function can be expressed as follows:

$h_{i j}(t)=\operatorname{Pr}\left(T_{i j}=t+1 \mid T_{i j}>t\right)=\Phi\left(x_{i t}, \beta_{j}\right)$,

where $\Phi(\cdot)$ is the standard normal cumulative density function, $x_{i t}$ is a vector of the covariates (some are time varying) that affect the survival and exit route of firm $i$, and $\beta_{j}$ denotes the parameters to be estimated.

However, the propensity to patent is likely to be affected by various factors. For example, some studies 
provide evidence that industry-specific characteristics, such as appropriability conditions and technological opportunity, affect the propensity to patent (e.g., Brouwer \& Kleinknecht, 1999; Ceccagnoli, 2009; Dindaroğlu, 2018). ${ }^{7}$ In addition, the propensity to patent may depend on a firm's life cycle, since knowledge is cumulative in nature. Some studies showed evidence that the propensity to patent changes according to firm age (e.g., Balconi \& Fontana, 2011). Therefore, patenting is considered as endogenous in the model. Estimating without taking into account endogeneity will lead to biased results. To deal with potential endogeneity, an instrumental variable (IV) probit model is the most desirable as an estimation model (Wooldridge, 2010). Therefore, in this study, we use an IV probit model to examine the effects of patenting on the survival of new firms according to exit route.

\subsection{Probability of exit routes}

Bankruptcy as involuntary liquidation is the situation in which firms cannot repay their debts and thus cease operations. Bankruptcy includes firms applying for court protection under Bankruptcy Law and those under the Corporate Rehabilitation Law or the Civil Rehabilitation Law. Additionally, despite the absence of a court judgment, firms are considered to be bankrupt when banks stop providing credit to service bills payable. Thus, bankruptcy includes not only legally bankrupt firms but also economically inactive ones. Undoubtedly, the occurrence of bankruptcy depends on the bankruptcy laws in the country. As pointed out by Peng et al. (2010), in Japan, even when financially insolvent firms decide to file for bankruptcy, courts will scrutinize the case and decide whether to allow certain firms to declare themselves bankrupt which can be a lengthy process (Lee et al., 2007; Peng et al., 2010). Meanwhile, it is often argued that Japanese firms with strong bank ties

\footnotetext{
${ }^{7}$ The European Patent Office (EPO) does not grant patents for computer programs ("software patents") or computer-implemented business methods that make no such technical contribution (European Patent Office, 2013). In Japan, software was made eligible for patent protection in 2000, and this protection was extended to software that circulates on computer networks in 2002 (Kani \& Motohashi, 2011). There are significant differences in the propensity to patent between the manufacturing and information services (software) sectors in our sample. The mean of a stock of citation-weighted patent application counts (this is defined later) is 0.390 in the manufacturing sector, while it is 0.310 in the information services sector. The mean is different at the $5 \%$ significance level ( $t$-test).
}

are more likely to avoid bankruptcy than firms without close bank ties, since the concentration of debt and equity enables the bank to restructure the firm's liabilities without relying on the coordinating role of bankruptcy courts (Suzuki \& Wright, 1985; Hoshi et al., 1991). In addition, because the exit mechanism of insolvency is generally not profitable for firms below a certain size and an insolvency procedure involves high transaction costs, debtors and creditors may prefer less formal agreements, such as voluntary liquidation (Harhoff et al., 1998). Bankruptcy is not a reasonable option for small firms in Japan, who usually opt instead for voluntary liquidation (Harada, 2007). The variable for bankruptcy (Bankruptcy) is defined as a dummy variable indicating 1 if the firm goes bankrupt between periods $t$ and $t+1,0$ if the firm survives.

Merger describes the situation in which firms disappear by being combined with other firms. The situation of M\&A markets differs between countries. Exit via M\&A is generally regarded as successful. However, in Japan, successful exit strategies via M\&A are much rarer than in the USA (Honjo \& Nagaoka, 2018). In practice, M\&As in Japan tend to be counter-cyclical, while US M\&As are procyclical (Mehrotra et al., 2011). This may be partly because M\&As are often employed to rescue financially distressed firms rather than to expand businesses during economic booms. Such "rescue mergers" occur when high-performing firms acquire important suppliers or subcontractors that are in financial distress (e.g., Kang et al., 2000; Kubo \& Saito, 2012; Honjo \& Nagaoka, 2018). ${ }^{8}$ The variable for exit via merger (Merger) is defined as a dummy variable indicating 1 if the firm exits via merger between periods $t$ and $t+1,0$ if the firm survives.

Voluntary liquidation describes the situation in which firms voluntarily dissolve their businesses without insolvency. Several reasons seem to exist for voluntary liquidation. While some entrepreneurs dissolve their businesses without insolvency due to poor performance, others voluntarily dissolve their businesses due to employment opportunities with high wages. Some entrepreneurs may choose to close their firms because

\footnotetext{
${ }^{8}$ Kubo and Saito (2012) reported that 31 of the 111 mergers involving Japanese companies listed between 1990 and 2003 were likely rescue mergers. According to Kang et al. (2000), rescue mergers represent instances where a bank, acting primarily as a creditor, forces a client firm to bail out another distressed firm for which the bank is also a creditor.
} 
they are approaching retirement age and have no successors. Japan, currently experiencing an aging population and declining birthrate, represents a unique context for voluntary liquidation. According to the Small and Medium Enterprise Agency (2014), the number of voluntary liquidations (e.g., company dissolution and business closure) in Japan doubled from 2003 to 2013; in the same period, bankruptcies declined by approximately $30 \%$. The most common reasons (cited by approximately half the respondents) for voluntary liquidation were managers' aging and health problems. Using data on small firms in Japan, Harada (2007) found that only $40 \%$ of firm exits were economically driven. The variable for voluntary liquidation (Voluntary) is defined as a dummy variable indicating 1 if the firm liquidates voluntarily the business between periods $t$ and $t+1,0$ if the firm survives.

We identify the exit year of new firms based on information on the accounting year of their final financial statements.

\subsection{Patent stock}

In this study, patenting is the main independent variable determining the survival of new firms. It is well known that the distribution of patent values is highly skewed toward the low end (Trajtenberg, 1990). Patent citations correspond to the number of times a patent has been cited in more recent patent applications, and thus are a proxy for the importance of a patent (Markman et al., 2004). A firm with a large number of cited patents is likely to possess technology that is central to developments in its industry, and such a firm exhibits the ability to produce innovative technologies that have had a strong influence on later developments in its industry (Breitzman \& Thomas, 2002). In practice, Narin et al. (1987) provide evidence on a positive relationship between highly cited patents and increased sales and profits in the pharmaceutical industry. Therefore, patent citations may represent firms' capabilities associated with survival and exit. In addition, highly cited patents may be highly evaluated in the markets for ideas. In practice, the value of patents is investigated in the due diligence of M\&A (Breitzman \& Thomas, 2002). Firms with highly cited patents are a more attractive target for merger. Even if firms with highly cited patents do not find a suitable partner for merger, they can sell their patents at a high price in the markets for ideas. These firms may receive a large amount of cash in the markets for ideas, which may promote voluntary liquidation (Balcaen et al., 2012).

Following Hall et al. (2001), we capture the value of patents by considering the number of forward citations. We measure an index for citation-weighted patent application counts (Patcite $_{i t}$ ) for firm $i$ in period $t$ as follows:

Patcite $_{i t}=\sum_{k}\left(1+\frac{\text { Cite }_{k t}}{\text { Acite }_{l t}}\right)$,

where $k$ represents firm $i$ 's patent applications, and Cite $_{k t}$ is the number of citations that patent application $k$ received divided by the average citation count for a group of patents to which the patent application of interest $k$ belongs $\left(A A_{-}\right.$cite $\left._{l t}\right)$, that is, technological area $l$ in application year $t .{ }^{\overline{9}}$ The index for a citation-weighted patent count is measured by adding 1 to the number of citations divided by the average citation, then the citation-weighted patent application count is aggregated at the firm level for each application year.

As already discussed, not only current investment in intangible assets but also previous intangible stock may affect new firm survival, since firms with a higher stock of patents have greater revenue potential (Buddelmeyer et al., 2010). In addition, firms' larger portfolio in terms of the number of patents puts the firms in a better bargaining position in negotiations (Blind et al., 2009; Noel \& Schankerman, 2013), and they can sell more patent rights and thus get a larger amount of cash. For these reasons, patenting should be measured as a stock rather than as a flow. Following previous studies (e.g., Griliches \& Mairesse, 1984; Hall, 1993; Hottenrott et al., 2016), we compute firm $i$ 's stock of citation-weighted patent application counts $\left(\right.$ Patst $\left._{i t}\right)$ in period $t$ using a constant depreciation rate $(\delta)$ of $15 \%$ per year as:

Patst $_{i t}=(1-\delta)$ Patst $_{i t-1}+$ Patcite $_{i t}$.

The ex post value of patents can be captured with the citation-weighted patent counts (Hall et al., 2005). We first measure the stock of citation-weighted patent application counts $\left(\right.$ Patst $_{i t}$ ) including both granted and non-granted patents. However, patentability requires novelty (and inventive steps) and utility (Nagaoka et al., 2010). In practice, about $50 \%$ of patent

\footnotetext{
${ }^{9}$ In this paper, technological area is defined using international patent classification (IPC) classes.
} 
applications in Japan were not granted during the observation period (2016 JPO Annual Statistics Report). ${ }^{10}$ While patent applications have been widely used as a measure of patenting activity (Hsu \& Ziedonis, 2013; Hoenen et al., 2014; Hall, 2019), the value of granted patents seems to differ from that of non-granted patents (Kline et al., 2019). In addition, firms can trade patent rights in the markets for ideas only when patents are granted. It is worthwhile identifying the value-added effects of granted patents as an intangible asset. To take into account the ex ante value of patents in terms of novelty, usefulness, and non-obviousness, we measure the stock of citation-weighted patents granted by the patent authority (Patst_gr $\left.r_{i t}\right)$ measured at the time of patent application.

\subsection{Instrumental variables}

In this study, patenting is considered as endogenous in the IV probit model, and some variables are used as instrumental variables. Specifically, appropriability and technological opportunity at the industry level are used as instrumental variables in this study. It has been recognized that firms have incentives to invest in $R \& D$ when they can appropriate returns from innovating (Arrow, 1962; Levin et al., 1987). In practice, the rate of patenting tends to increase under strong appropriability conditions (Dindaroğlu, 2018). While industries differ widely in the extent to which patents are effective (Cohen, 2010), interindustry differences in innovation activities tend to be persistent (Cefis \& Orsenigo, 2001). The appropriability measure has been used as a variable instrumented for patent propensity in previous studies (e.g., Ceccagnoli, 2009). In addition, firms are more likely to have incentives to innovate when technological opportunity is high (e.g., Nelson \&

\footnotetext{
${ }^{10}$ As of 2003, the rate of granted patents among total patent applications to the JPO was $49.9 \%$, while it was $59.9 \%$ for the European Patent Office and $64 \%$ for the US Patent and Trademark Office (USPTO, 2004). Many patents applied for to the JPO have not been granted. According to Nagaoka (2009), one reason for the low grant rate may be that the JPO has applied stricter standards for patent quality since 2000, particularly regarding inventive steps. To grant patents in Japan, applicants need to request examination within 3 years from the filing date by the applicant or a third party, while there is no such a system in the USA. Another reason for the low grant rate in Japan might be because procedural costs are quite low at the time of patent application (van Pottelsberghe de la Potterie \& François, 2009), but applicants are required to pay more than ten times those fees $(168,000$ yen) to request an examination, according to the JPO official webpage, in contrast to the application fees (15,000 yen) as of 2004 .
}

Wolff, 1997). In practice, Brouwer and Kleinknecht (1999) showed evidence that sectors with high technological opportunity tend to have a higher propensity to patent than sectors with low technological opportunity. Meanwhile, there should be heterogeneity in firm performance within industries. While firm performance (e.g., survival and exit) is contingent on the firm's strategy (e.g., patenting), the strategy depends on industry conditions, including appropriability and technological opportunity. For these reasons, industry appropriability and technological opportunity are likely correlated with the decision of patenting, while it can be assumed that they are uncorrelated with the error term of the equation for exit routes.

Following Levin et al. (1984, 1987), appropriability (Appro) is defined as the extent to which the innovative outcomes can be appropriated by the innovators themselves, while technological opportunity denotes the availability of useful information for innovation. The variable for appropriability is calculated based on the survey's scores regarding the effectiveness of nine methods of appropriation (e.g., patents to prevent duplication or to secure royalties, secrecy, lead time). The variable for technological opportunity (Tech) is calculated based on the survey's scores regarding the importance of external sources of knowledge for an industry's technological advance (e.g., suppliers, customers, competitors, government agencies and research labs). We constructed these variables in the same way as previous studies based on Japanese data (e.g., Goto \& Nagata, 1997; Okamuro et al., 2011).

\subsection{Control variables}

Several control variables are included in the model. First, a dummy variable for the founders' patent applications before founding (Pre pat), which represents technological experience, is included as a control variable in the model since firms managed by founders with higher levels of human capital are more likely to exhibit superior performance (Kato et al., 2015). Additionally, founders with more technological experience may have more information on potential market demand and opportunities than those with less (Gruber et al., 2013). Furthermore, we controlled for the effect of firm size (Size), defined as the number of employees in the first year of observation, on new firm survival because the probability of survival is found to increase with firm size (Audretsch, 1991; Audretsch \& Mahmood, 1991, 1995; 
Geroski, 1995; Cefis \& Marsili, 2011, 2012). Additionally, we include a variable for firm age (Age firm), defined as the number of years from a firm's foundation. As indicated by previous studies, survival and exit depend heavily on firm age (Evans, 1987; Geroski, 1995; Fontana \& Nesta, 2009; Cefis \& Marsili, 2011, 2012); specifically, firms with a longer history are more likely to survive than newer firms because of learning effects and cumulative knowledge.

Regarding founder-specific characteristics, the founder's age (Age founder) is included to control for differences in opportunity costs and risk propensity among founders (Levesque \& Minniti, 2006; De Jong \& Marsili, 2015). Following previous studies, founders' educational backgrounds are considered as a determinant of firm survival (Bates, 1990; Cooper et al., 1994; Kato \& Honjo, 2015); thus, dummies for founders' educational backgrounds ( $E d u$ and $E d u \_X$ ) are included in the model. Moreover, cohort dummies (eight cohorts for the different years of entry) are included. Table 3 presents the definitions of the variables.

\section{Data}

\subsection{Data sources}

The data set comes from COSMOS2, compiled by Teikoku Databank Ltd. (TDB), a major credit reporting company in Japan. COSMOS2 mainly collects information on incorporated firms, such as joint-stock companies, rather than sole proprietorships and partnerships. It provides basic information on founder- and firm-level characteristics, such as founders' educational background and dates of birth, number of employees, and industry codes. ${ }^{11}$ It also provides information on whether a firm exits and its exit route.

The data set consists of 5270 joint-stock companies with fewer than 50 employees at the first year of observation in the manufacturing (3246 firms) and information services (software) sectors (2024 firms), founded

\footnotetext{
${ }^{11}$ As another data source, the Establishment and Enterprise Census reports data such as the number of entries and exits at the establishment level for individual industries or regions. However, it is difficult to obtain data for individual firms from this data source and, generally, we could not use the source to identify which establishments (or firms) have become active or extinct. Additionally, reliance on the source is accompanied by the possibility that relocations of establishments to other regions might be recorded as exits even if the establishments remain in the market.
}

Table 3 Definitions and summary statistics of variables

\begin{tabular}{ll}
\hline Variable & Definition \\
\hline $\begin{array}{l}\text { (Dependent variable) } \\
\text { Bankruptcy }\end{array}$ & $\begin{array}{c}\text { Dummy variable: } 1 \text { if the firm goes bankrupt } \\
\text { between periods } t \text { and } t+1,0 \text { if the firm survives. }\end{array}$ \\
Merger & $\begin{array}{c}\text { Dummy variable: } 1 \text { if the firm exits via merger } \\
\text { between periods } t \text { and } t+1,0 \text { if the firm survives. }\end{array}$ \\
Voluntary & $\begin{array}{c}\text { Dummy variable: } 1 \text { if the firm voluntarily } \\
\text { liquidates the business between periods } t \text { and } \\
t+1,0 \text { if the firm survives. }\end{array}$
\end{tabular}

(Endogenous variable)

Patst A stock of citation-weighted patents applied by the firm in period $t$.

Patst_gr A stock of citation-weighted patents granted by the patent authority among patents applied by the firm in period $t$.

(Control variable)

Pre pat Dummy variable: 1 if the founder has experience of patent applications, 0 otherwise.

Size Logarithm of the number of employees in the first year of observation.

Age firm Number of years after the foundation for the firm in period $t$.

Age founder Founders' age at founding.

Edu_univ Dummy variable: 1 if the founder had a university education before founding, 0 otherwise.

$E d u \quad X \quad$ Dummy variable: 1 if the educational background of the founder is unknown, 0 otherwise.

(Instrumental variable)

Appro Industry's degree of appropriability of innovation outcomes.

Tech Industry's degree of technological opportunities.

between 2003 and 2010 and includes information on the survival and exit of firms from their foundation years to 2013. ${ }^{12}$ Some firms are regarded as censored before 2013 during the observation period, since TDB cannot track the firms' information anymore (e.g., relocation for unknown reasons). ${ }^{13}$ In this study, we focus on jointstock companies by excluding sole proprietorships and partnerships from the sample. Furthermore, this study targets new firms in the manufacturing and information

\footnotetext{
$\overline{12}$ Table 8 in the Appendix shows the industry distribution in the sample used in this study.

${ }^{13}$ As a robustness check, we estimated the model by excluding from the sample firms that are censored during the observation period. However, the results do not change significantly.
} 
services sectors because of their high R\&D intensity and patent propensity.

To match the above data set with a patent database, we employ the IIP Patent Database compiled by the Institute of Intellectual Property (IIP), Japan Patent Office (JPO). This database covers all patent applications to the JPO since $1964 .{ }^{14}$ Using this database, we identify patent applications by firms based on their names and addresses.

Data on industry-specific characteristics used as instrumental variables, such as the appropriability of innovation output and technological opportunities, are obtained from the Report on the National Innovation Survey 2003, compiled by the National Institute of Science and Technology Policy (NISTEP) of the Ministry of Education, Culture, Sports, Science and Technology (MEXT).

\subsection{Descriptive statistics}

Table 4 shows the life table for survival according to exit route by the year of foundation. The sample included eight cohorts from 2003 to 2010. Among them, there are approximately 500 firms founded between 2003 and 2005. The number of newly founded firms for each cohort increased from 2006 when a regulation for minimum capital requirement was abolished in Japan (Honjo \& Kato, 2019). ${ }^{15}$ Many firms survived during the observation period and they were censored at the end of 2013. Among the 5270 firms in the sample, 624 (about 12\%) had exited by 2013 . The largest number of exits was voluntary liquidation (229) followed by bankruptcy (217) and merger (178). The exit rate in the sample seems much lower than found in previous studies (e.g., Dunne et al., 1988; Audretsch, 1995; Bartelsman et al., 2005). This is because we focus on joint-stock companies by excluding sole proprietorships and partnerships from the sample.

Figure 1 describes the pattern of exits for each route during the observation period, according to year and firm age. The exit rate is defined as the number of exits over the number of firms at risk (shown as a percentage). In the upper figure, for example, the exit rate via merger is $0.4 \%$ in 2003 and zero for the other exit routes in the same year. As shown, the exit rates in all forms increase

\footnotetext{
${ }^{14}$ For more details on this database, see Goto and Motohashi (2007).

${ }^{15}$ Under this amendment of the Commercial Act, enacted in April 1990, when a joint-stock company was newly founded in Japan, paidin capital of at least 10 million yen was required at founding. This regulation was removed by the introduction of the new Companies Act in May 2006, which superseded the Commercial Act.
}

during the observation period. ${ }^{16}$ Similarly, the exit rates in all forms increase according to firm age, while those of voluntary liquidation peaked at the third year and then declined over time. While many studies have provided evidence that the probability of exit decreases with firm age, recent studies have indicated that age dependence is eliminated after controlling for firm quality, such as pre-entry performance and firm size (Thompson, 2005; Coad, 2018). Moreover, Fig. 1 seems consistent with the finding of Esteve-Pérez and MañezCastillejo (2008) who reported that the hazard rate increases as firms age up to 20 years, then declines up to 35 years, to finally increase again. In Japan, the bankruptcy rate is relatively low in the early years after foundation, partly because, as discussed in Section 2, bankruptcy takes a long time to complete.

Table 5 shows the summary statistics and correlation matrix of variables. The mean of a stock of citationweighted patent application counts (Patst) is 0.358 . The means of a stock of citation-weighted granted patent counts (Patst_gr) is 0.148 , indicating that $41 \%$ of patent applications are granted for new firms in the sample. The value of Patst is more than zero in 2200 among 31,400 observations (7\%), although that is not shown in this table. Similarly, the value of Patst_gr is more than zero in 1031 observations (3.3\%). As for founders' previous patent applications (Pre_pat), 318 founders $(6 \%)$ in the sample had experience in patent applications before founding their firms. Furthermore, the average number of employees in the sample firms are approximately nine. The average age of founders at the time of founding is approximately 47 years.

The correlation matrix of variables shows that Patst and Patst_gr are not significantly correlated to exit routes. Pre pat is positively and significantly correlated to Merger and Voluntary. It is also positively correlated to Patst and Patst_gr, indicating that founders' patenting experience affects the firms' patent propensity. Size is positively and significantly correlated to Bankruptcy and Merger, while it is positively associated with Patst and Patst_gr. Age firm is positively correlated to Bankruptcy and Merger, while it is positively associated with Patst and Patst_gr. These observations suggest that exit

\footnotetext{
${ }^{16}$ To control for macroeconomic conditions, we estimated the model by inserting year dummies. These variables did not affect significantly all forms of exit. Therefore, we do not report the results using year dummies.
} 


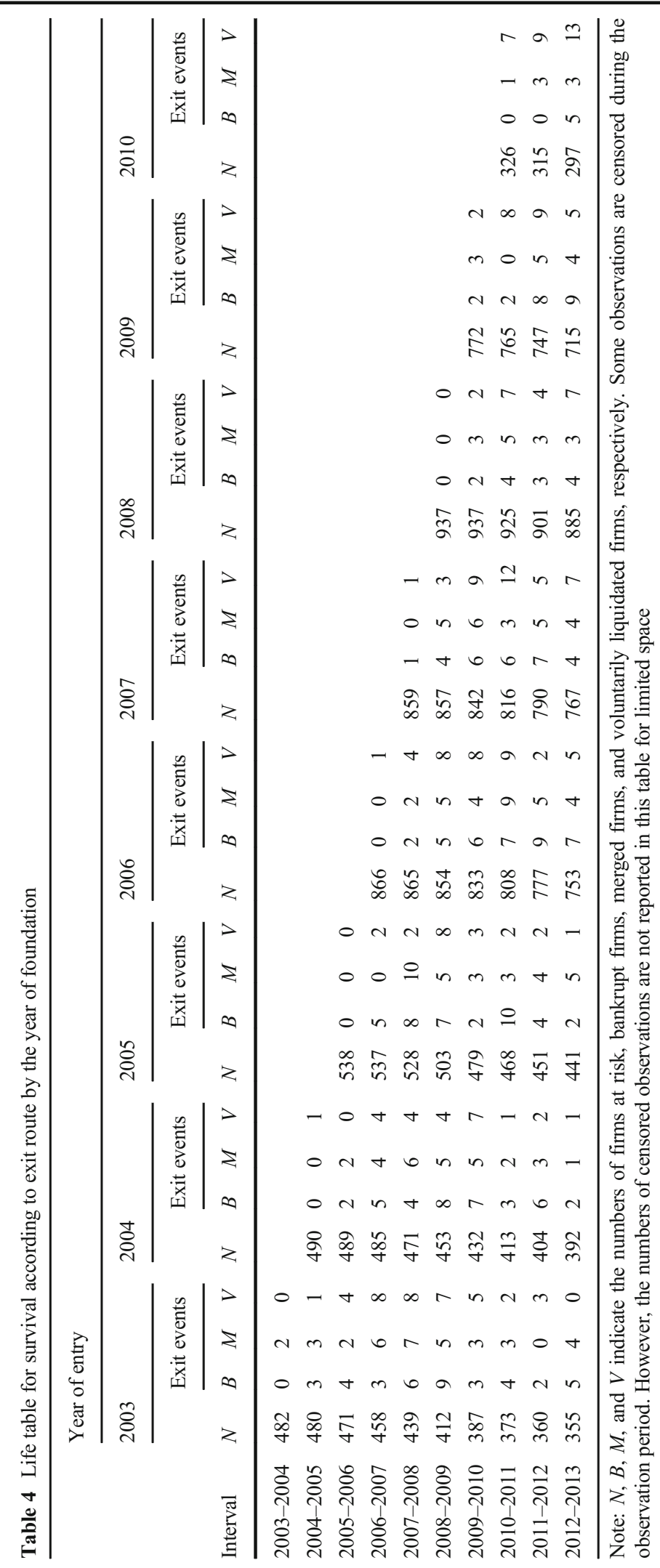


Fig. 1 Exit rates according to observation years (upper) and firm age (lower)
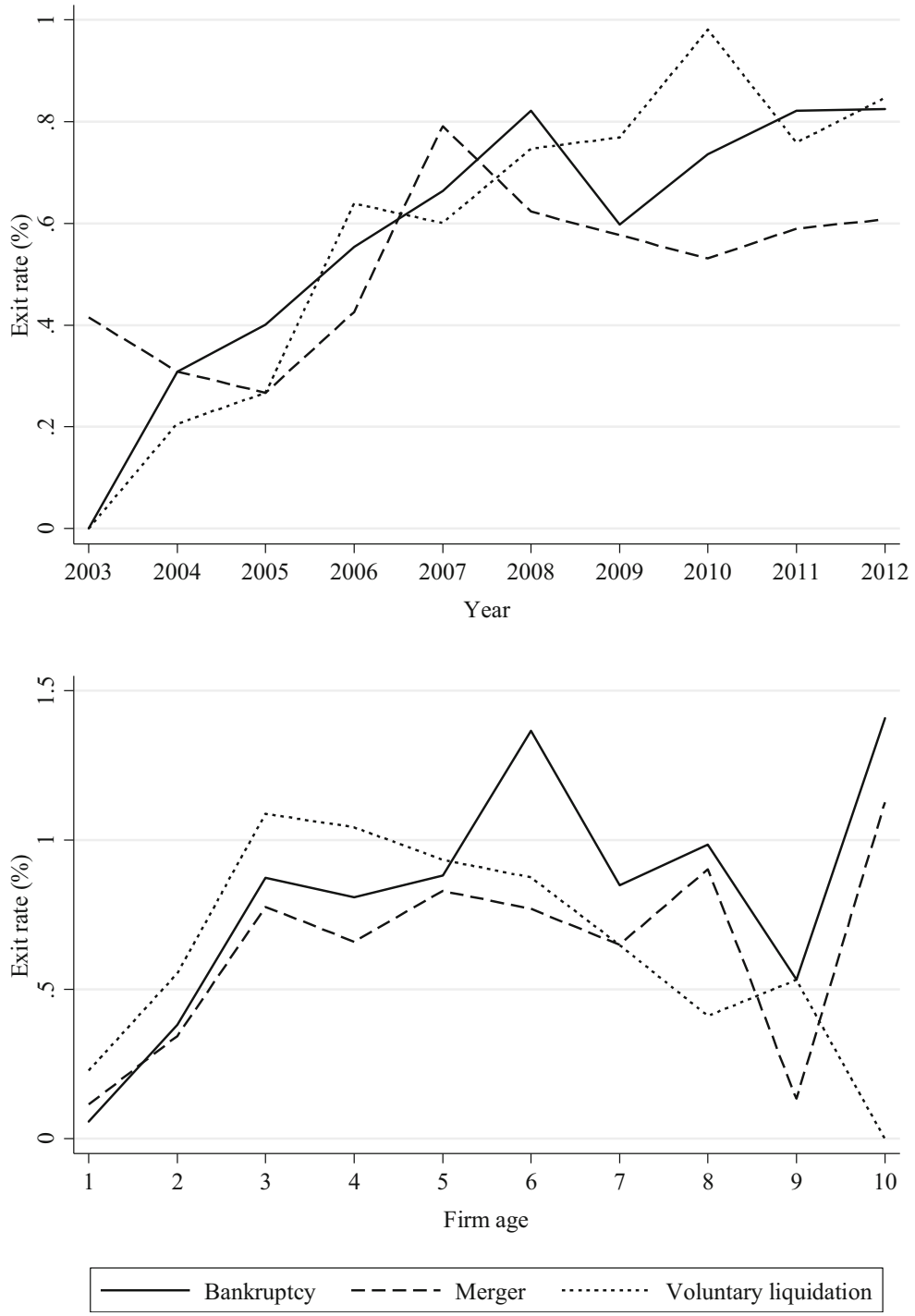

probabilities via bankruptcy and merger increase with firm size and age, and firms' propensity to patent tends to increase with size and age. As for founderspecific characteristics, Age founder is positively associated with all forms of exit and patent variables (Patst and Patst_gr). Edu is positively correlated to Voluntary and patenting variables. These observations suggest that we should take into account the endogeneity of patent variables in our model, since patenting is likely to be affected by a number of factors, such as founders' patenting experience, firm size, and firm age. Appro and Tech used as instrumental variables are positively correlated to patent variables (Patst and Patst_gr), and the correlation coefficients are strongly significant at the $1 \%$ significance level. In contrast, these variables are not significantly correlated to all forms of exit. This indicates that the instrumental variables satisfy the conditions that they are not correlated to the exit decisions of firms as the dependent variables.

\section{Results}

\subsection{Estimation results}

Using the IV probit model, we estimated the effects of patenting on new firm survival according to exit route. The estimation results are shown in Table 6, when the stock of citation-weighted patent application counts 


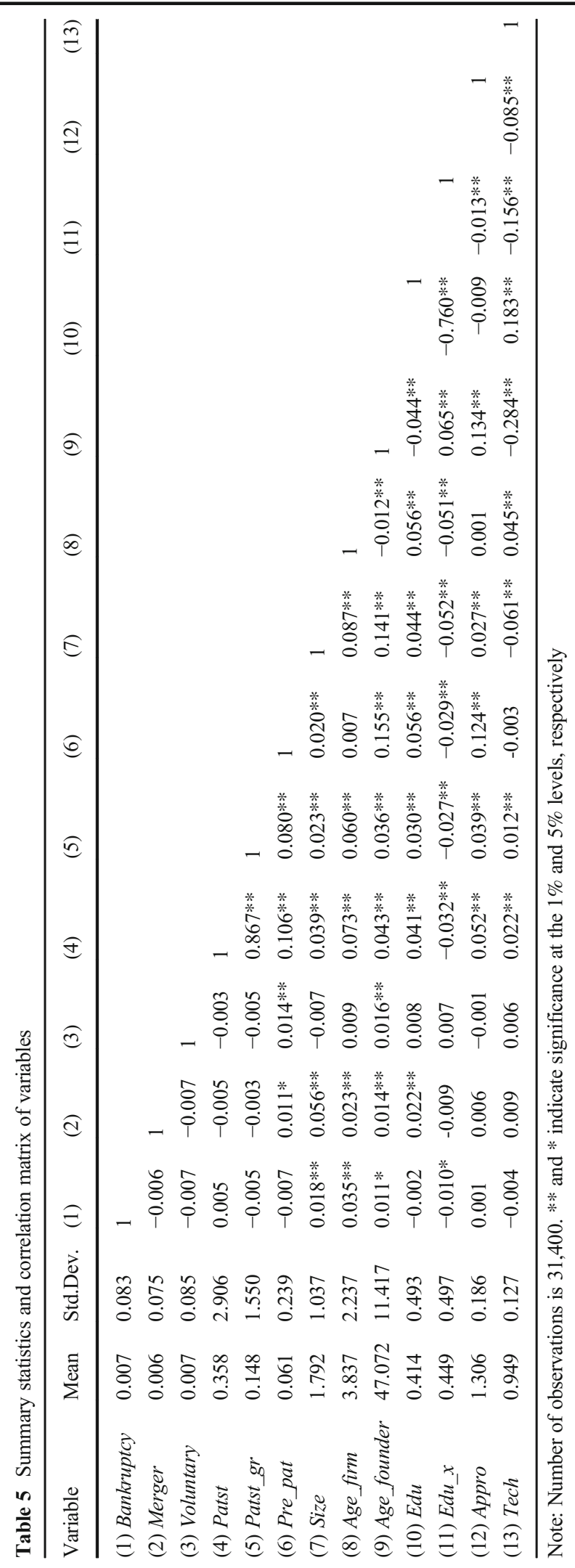


(Patst) is used as the variable for patenting. The estimation results using the stock of citation-weighted granted patent counts (Patst_gr) are shown in Table 7. For both the tables, the results for the determinant of exit routes are shown in columns (i), (iii), and (v), while those from the first-stage regressions determining patenting are presented in columns (ii), (iv), and (vi). As seen in the bottom panels of Tables 6 and 7, the Wald tests of exogeneity of the instrumented variables indicate that the null hypothesis of no endogeneity, except for the case of voluntary liquidation as a route to exit in Table 6 , is rejected. This means that the IV probit model should be used instead of a regular probit model.

As for the determinants of patenting in the first stage regression in Table 6, both Appro and Tech as (additional) instrumental variables have positive and significant effects on Patst. ${ }^{17}$ Pre pat has positive effects on Patst, indicating that firms whose founders have patenting experience are more likely to have a higher patent application stock. ${ }^{18}$ Age firm has positive and significant effects on Patst, indicating that the propensity to patent tends to rise with firm age. $E d u$ has positive and significant effects on Patst, indicating that firms managed by founders with higher educational backgrounds are more likely to have a higher patent application stock. Turning to Table 7, the results of the first stage regressions are generally consistent with those of Table 6, while the coefficients and significance levels for founder-specific variables changed slightly.

Next, we discuss the effects of patenting on exit routes. With respect to Bankruptcy, column (i) of Table 6 shows the effect of the stock of citation-weighted patent applications (Patst) is negative and statistically significant at the $1 \%$ significance level, indicating that firms with a higher stock of patent applications are less likely to go bankrupt. Similarly, the effect of the stock of citationweighted granted patents (Patst_gr) on Bankruptcy is negative and statistically significant at the $1 \%$ significance level in column (i) of Table 7, indicating that firms with a higher stock of granted patents are less likely to go bankrupt. Hypothesis 1 is supported with these findings.

\footnotetext{
${ }^{17}$ The $F$-test for weak-instrument cannot be done in the IV probit model. Instead, we estimated an IV regression and found that the $F$ value in the first stage regression exceeds 10 , suggesting that our instruments are not weak. We estimated the model using Appro only as an additional instrumental variable. The results are generally consistent with those of Tables 6 and 7.

${ }^{18}$ This is consistent with the finding of Balconi and Fontana (2011) that successful inventors are more likely to be serial patentees.
}

The findings suggest that patenting is an essential strategy to compete and survive successfully in product markets. It concurs with the RBV that patents are an important resource for new firms to protect inventions and attract customers and external providers of capital. As a result, patenting firms can obtain competitive advantage, thereby reducing the risk of business failure.

Turning to the effects of patenting on Merger, the effect of the stock of citation-weighted patent applications (Patst) is positive and statistically significant at the $1 \%$ significance level in column (iii) of Table 6 , indicating that firms with a higher stock of patent applications are more likely to exit via merger. The effect of the stock of citationweighted granted patents (Patst gr) on Merger is positive and statistically significant in column (iii) of Table 7 , indicating that new firms with a higher stock of granted patents are more likely to exit via merger. Our findings are consistent with those of previous studies, including Cotei and Farhat (2018), and Hypothesis 2 is supported. These findings suggest that patenting firms become more attractive targets for M\&A by other firms. They also suggest that accumulating technological knowledge as well as holding patent rights as intangible assets are highly evaluated in markets for ideas. It concurs with the RBV that patents are a highly valuable resource in the markets.

As for the effects of patenting on voluntary liquidation, the stock of citation-weighted patent applications (Patst) has no significant effect on Voluntary in column (v) of Table 6. This indicates that new firms with a higher stock of patent applications do not necessarily opt for voluntary liquidation. As discussed in the previous section, only $41 \%$ of patent applications are granted in the sample as a result of examination in terms of novelty, usefulness, and non-obviousness. If firms get rejected for their patent applications, they are not able to hold patent rights and thus cash out their inventions in markets for ideas. As a result, such firms may not be different from non-patenting firms in terms of the propensity of voluntary liquidation. In contrast, the stock of citation-weighted granted patents (Patst gr) has a positive and statistically significant effect on Voluntary in column (v) of Table 7 , indicating that new firms with a higher stock of granted patents are more likely to voluntarily close their businesses without insolvency. In this respect, Hypothesis 3 is generally supported. The findings suggest the importance of patents as intangible assets in markets for ideas.

Regarding the effects of control variables, founders' patent applications before founding (Pre pat) have a negative and significant effect on the probability of exit 
Table 6 Estimation results for IV Probit regressions: effects of patent application stock (Patst) on exit routes

\begin{tabular}{|c|c|c|c|c|c|c|}
\hline \multirow[b]{2}{*}{ Variable } & \multicolumn{2}{|l|}{ Bankruptcy } & \multicolumn{2}{|l|}{ Merger } & \multicolumn{2}{|c|}{ Voluntary liquidation } \\
\hline & (i) Bankruptcy & (ii) Patst & (iii) $M e r g e r$ & (iv) Patst & (v) Voluntary & (vi) Patst \\
\hline \multicolumn{7}{|l|}{ Endogenous variable } \\
\hline Patst & $\begin{array}{l}-0.097 * * * \\
(0.012)\end{array}$ & & $\begin{array}{l}0.212 * * * \\
(0.000)\end{array}$ & & $\begin{array}{l}0.121 \\
(0.077)\end{array}$ & \\
\hline \multicolumn{7}{|l|}{ Control variable } \\
\hline Pre_pat & $\begin{array}{l}-0.063^{* * *} \\
(0.020)\end{array}$ & $\begin{array}{l}1.145 * * * \\
(0.253)\end{array}$ & $\begin{array}{l}-0.195 * * * \\
(0.004)\end{array}$ & $\begin{array}{l}1.145^{* * *} \\
(0.253)\end{array}$ & $\begin{array}{l}-0.009 \\
(0.111)\end{array}$ & $\begin{array}{l}1.145 * * * \\
(0.252)\end{array}$ \\
\hline Size & $\begin{array}{l}0.058 \\
(0.047)\end{array}$ & $\begin{array}{l}0.065 \\
(0.052)\end{array}$ & $\begin{array}{l}0.175 * * * \\
(0.024)\end{array}$ & $\begin{array}{l}0.065 \\
(0.052)\end{array}$ & $\begin{array}{l}-0.020 \\
(0.018)\end{array}$ & $\begin{array}{l}0.065 \\
(0.052)\end{array}$ \\
\hline Age firm & $\begin{array}{l}0.063 * * * \\
(0.013)\end{array}$ & $\begin{array}{l}0.078 * * * \\
(0.021)\end{array}$ & $\begin{array}{l}0.010 * \\
(0.005)\end{array}$ & $\begin{array}{l}0.078 * * * \\
(0.021)\end{array}$ & $\begin{array}{l}0.025 * * * \\
(0.001)\end{array}$ & $\begin{array}{l}0.078 * * * \\
(0.021)\end{array}$ \\
\hline Age_founder & $\begin{array}{l}0.005 \\
(0.003)\end{array}$ & $\begin{array}{l}0.007 \\
(0.004)\end{array}$ & $\begin{array}{l}0.000 \\
(0.000)\end{array}$ & $\begin{array}{l}0.007 * \\
(0.004)\end{array}$ & $\begin{array}{l}0.004 \\
(0.004)\end{array}$ & $\begin{array}{l}0.007 \\
(0.005)\end{array}$ \\
\hline$E d u$ & $\begin{array}{l}-0.154^{* * *} \\
(0.005)\end{array}$ & $\begin{array}{l}0.136 * * \\
(0.065)\end{array}$ & $\begin{array}{l}0.260 * * * \\
(0.013)\end{array}$ & $\begin{array}{l}0.135 * * \\
(0.065)\end{array}$ & $\begin{array}{l}0.314 * * * \\
(0.015)\end{array}$ & $\begin{array}{l}0.135 * * \\
(0.064)\end{array}$ \\
\hline$E d u \_X$ & $\begin{array}{l}-0.189^{* * * *} \\
(0.002)\end{array}$ & $\begin{array}{l}-0.011 \\
(0.150)\end{array}$ & $\begin{array}{l}0.213 \text { *** } \\
(0.035)\end{array}$ & $\begin{array}{l}-0.011 \\
(0.150)\end{array}$ & $\begin{array}{l}0.317 * * * \\
(0.031)\end{array}$ & $\begin{array}{l}-0.011 \\
(0.150)\end{array}$ \\
\hline \multicolumn{7}{|l|}{ Instrumental variable } \\
\hline Appro & & $\begin{array}{l}0.588 * * * \\
(0.069)\end{array}$ & & $\begin{array}{l}0.576^{* * * *} \\
(0.075)\end{array}$ & & $\begin{array}{l}0.581 * * * \\
(0.061)\end{array}$ \\
\hline Tech & & $\begin{array}{l}0.590 * * * \\
(0.016)\end{array}$ & & $\begin{array}{l}0.619 * * * \\
(0.004)\end{array}$ & & $\begin{array}{l}0.606 * * * \\
(0.030)\end{array}$ \\
\hline Constant term & $\begin{array}{l}-2.767^{* * *} \\
(0.110)\end{array}$ & $\begin{array}{l}-1.740^{* * *} \\
(0.562)\end{array}$ & $\begin{array}{l}-2.500 * * * \\
(0.084)\end{array}$ & $\begin{array}{l}-1.756^{* * *} \\
(0.551)\end{array}$ & $\begin{array}{l}-2.867^{* * * *} \\
(0.445)\end{array}$ & $\begin{array}{l}-1.749 \text { *** } \\
(0.570)\end{array}$ \\
\hline Cohort dummies & Yes & Yes & Yes & Yes & Yes & Yes \\
\hline Number of observations & 31400 & & 31400 & & 31400 & \\
\hline Log pseudolikelihood & -78970.765 & & -78734.243 & & -79020.394 & \\
\hline Wald test of exogeneity (chi2) & $37.46^{* * *}$ & & $10180.00 * * *$ & & 1.980 & \\
\hline
\end{tabular}

Notes: Robust standard errors are in parentheses. $* * *, * *$, and $*$ indicate significance at the $1 \%, 5 \%$, and $10 \%$ levels, respectively

via bankruptcy and merger in Table 6, while it is not significant in column (i) of Table 7, suggesting that new firms managed by founders with technological experience before founding are less likely to go bankrupt and exit via merger than those managed by founders without such experience. Firm size (Size) has a positive effect on exit via merger, as seen in Tables 6 and 7, indicating that larger firms are more likely to be targets of merger. Furthermore, firm age (Age firm) has a positive effect on all forms of exit in Tables 6 and 7. The results indicate that the probability of exit, regardless of exit route, increases with age. While many studies have stated that the probability of exit decreases with firm age, our finding is consistent with the finding of Esteve-
Pérez and Mañez-Castillejo (2008) that the hazard rate increases as the firm ages up to 20 years. As for founderspecific characteristics, founders' age (Age founder) has a positive and significant effect on exits via bankruptcy and voluntary liquidation in columns (i) and (v) of Table 7. Regarding the founders' educational background, university education $(E d u)$ has a negative and significant effect on the probability of bankruptcy, indicating that new firms managed by highly educated founders are less likely to go bankrupt. However, this variable has a positive and significant effect on the probability of merger and voluntary liquidation, indicating that new firms managed by highly educated founders are more likely to exit via merger or voluntary 
Table 7 Estimation results for IV Probit regressions: effects of granted patent stock (Patst_gr) on exit routes

\begin{tabular}{|c|c|c|c|c|c|c|}
\hline \multirow[b]{2}{*}{ Variable } & \multicolumn{2}{|l|}{ Bankruptcy } & \multicolumn{2}{|l|}{ Merger } & \multicolumn{2}{|c|}{ Voluntary liquidation } \\
\hline & (i) Bankruptcy & (ii) Patst_gr & (iii) Merger & (iv) Patst_gr & (v) Voluntary & (vi) Patst_gr \\
\hline \multicolumn{7}{|l|}{ Endogenous variable } \\
\hline \multirow[t]{2}{*}{ Patst_gr } & $-0.248 * * *$ & & $0.487 * * *$ & & $0.263 * * *$ & \\
\hline & $(0.084)$ & & $(0.036)$ & & $(0.058)$ & \\
\hline \multicolumn{7}{|l|}{ Control variable } \\
\hline \multirow[t]{2}{*}{ Pre_pat } & -0.074 & $0.458 * *$ & $-0.170 * *$ & $0.458 * *$ & 0.003 & $0.458 * *$ \\
\hline & $(0.051)$ & $(0.205)$ & $(0.084)$ & $(0.205)$ & $(0.056)$ & $(0.205)$ \\
\hline \multirow[t]{2}{*}{ Size } & 0.055 & 0.011 & $0.159 * * *$ & 0.012 & -0.015 & 0.011 \\
\hline & $(0.050)$ & $(0.030)$ & $(0.022)$ & $(0.030)$ & $(0.018)$ & $(0.030)$ \\
\hline \multirow[t]{2}{*}{ Age firm } & $0.063 * * *$ & $0.031 * * *$ & $0.008 * *$ & $0.031 * * *$ & $0.025 * *$ & $0.031 * * *$ \\
\hline & $(0.013)$ & $(0.009)$ & $(0.004)$ & $(0.009)$ & $(0.012)$ & $(0.009)$ \\
\hline \multirow[t]{2}{*}{ Age founder } & $0.005^{*}$ & $0.003 * * *$ & -0.001 & $0.004 * * *$ & $0.004 *$ & $0.004 * * *$ \\
\hline & $(0.003)$ & $(0.001)$ & $(0.001)$ & $(0.001)$ & $(0.002)$ & $(0.001)$ \\
\hline \multirow[t]{2}{*}{$E d u$} & $-0.160 * * *$ & 0.029 & $0.237 * * *$ & 0.028 & $0.312 * * *$ & 0.029 \\
\hline & $(0.017)$ & $(0.031)$ & $(0.085)$ & $(0.032)$ & $(0.052)$ & $(0.031)$ \\
\hline \multirow[t]{2}{*}{$E d u \_X$} & $-0.196 * * *$ & -0.032 & $0.197 * * *$ & -0.032 & $0.313 * * *$ & -0.032 \\
\hline & $(0.004)$ & $(0.084)$ & $(0.069)$ & $(0.084)$ & $(0.013)$ & $(0.084)$ \\
\hline \multicolumn{7}{|l|}{ Instrumental variable } \\
\hline \multirow{2}{*}{ Appro } & & $0.228 * * *$ & & $0.220 * *$ & & $0.224 * * *$ \\
\hline & & $(0.076)$ & & $(0.086)$ & & $(0.078)$ \\
\hline \multirow[t]{2}{*}{ Tech } & & $0.187 * *$ & & $0.210 * *$ & & $0.199 * *$ \\
\hline & & $(0.087)$ & & $(0.100)$ & & $(0.087)$ \\
\hline \multirow[t]{2}{*}{ Constant term } & $-2.754 * * *$ & $-0.604 * *$ & $0.297 * *$ & $0.431 * * *$ & $-2.186^{* * *}$ & $-0.618 * *$ \\
\hline & $(0.252)$ & $(0.249)$ & $(0.133)$ & $(0.119)$ & $(0.535)$ & $(0.251)$ \\
\hline Cohort dummies & Yes & Yes & Yes & Yes & Yes & Yes \\
\hline Number of observations & 31,400 & & 31,400 & & 31,400 & \\
\hline Log pseudolikelihood & -59358.017 & & -59125.116 & & -59409.003 & \\
\hline Wald test of exogeneity (chi2) & $4.97 * *$ & & $9.31 * * *$ & & $12.33 * * *$ & \\
\hline
\end{tabular}

Notes: Robust standard errors are in parentheses. $* * *, * *$, and $*$ indicate significance at the $1 \%, 5 \%$, and $10 \%$ levels, respectively

liquidation. These results are generally consistent with those of Kato and Honjo (2015).

\subsection{Robustness checks}

We conduct some additional estimations to ensure the robustness of our findings. First, we estimate the model using a variable for the logarithm of current sales size in period $t$, since firm performance may be important to survival (e.g., Coad et al., 2013; Coad, 2018). ${ }^{19}$ The

\footnotetext{
${ }^{19}$ We further estimated the model by including sales growth measured as the log-differences of sales at founding year and at period $t$ divided by the number of years after foundation. This variable was not significant for all forms of exit; therefore, we do not report it.
}

sample size is reduced due to some missing values (from 31,400 to 27,257). Table 9 in the Appendix shows the estimation results when the stock of citation-weighted granted patents (Patst_gr) is used as the variable for patenting. The results indicate that the effects of patenting are generally consistent with Table 7 , while the current sales size significantly affects exit via voluntary liquidation.

Second, while the maximum age for a "new" firm in our sample is 10 years, previous studies have used different cut-off points in their definition of new firms; some have selected cut-off values of 6 or 8 years (Song et al., 2008; Cefis \& Marsili, 2011). Therefore, we run the model with a 
restriction on the maximum firm age of 8 years ${ }^{20}$; the results are shown in Table 10 in the Appendix. These results are generally consistent with those shown in Table 7.

Third, we run a version of the model that excluded firms whose founders have experience in patent applications before founding to avoid an endogeneity problem, as such firms possess higher patent propensity; those results are shown in Table 11 in the Appendix and are generally consistent with those shown in Table 7.

\section{Discussion and conclusions}

\subsection{Summary and contributions}

This study examined the role of patenting in determining new firm survival according to exit routes. To do so, we constructed a large-scale sample of new firms in the Japanese manufacturing and information services sectors from 2003 to 2013. By distinguishing among bankruptcy, merger, and voluntary liquidation, this study shows sharp differences in the effects of patenting on new firm survival according to exit route. We found that while patenting lowers the probability of bankruptcy, it increases the probability of merger, regardless of patent measures used (applied or granted patent stock). In addition, we provided evidence that patenting increases the probability of voluntary liquidation only when granted patent stock is used as a variable for patenting. From the RBV, this study emphasizes the importance of patents as a valuable resource, ensuring competitive advantage in product markets and providing "bargaining chips" in markets for ideas.

This study contributes to the literature on the effects of patenting on firms' exit. First, this study examined how the effects of patenting vary according to exit route, which is not well understood in the literature. As shown, there are sharp differences in the effects of patenting between the three routes to exit. Second, we estimated the model for the effects of patenting on exit routes while taking into account the endogeneity of patenting. Although previous studies, including Helmers and Rogers (2010), tend to ignore the endogeneity of

\footnotetext{
${ }^{20}$ The results using a sample restricting the maximum age to six years are also consistent with those using the full sample.
}

patenting in their model, patenting is clearly a strategic decision for firms. By estimating the IV probit model, we clarified the effects of patenting on exit routes rather than simply showing correlations. Third, whereas previous studies have largely used applications as a measure of patenting, there is huge heterogeneity in quality among patents, and highly cited patents represent a particularly valuable resource (Wagner \& Cockburn, 2010). By distinguishing between applied and granted patents (ex ante value of patents), as well as calculating patent stock adjusted by forward citations (ex post value of patents), we provided evidence on whether and how patent quality matters for new firm survival. In practice, while patent applications do not significantly affect voluntary liquidation, granted patents shows the significant effect on voluntary liquidation.

\subsection{Practical implications}

This study has some practical implications. First, the findings suggest that accumulating high-quality patents can help new firms avoid bankruptcy in product markets, though acquiring and enforcing IP rights is costly, especially for small firms, due to large fixed costs (Lanjouw \& Schankerman, 2004; Jensen \& Webster, 2006). However, few new firms have their own IP professionals. Thus, from the perspective of economic policy, it is worth providing support for new firms' IP acquisition and enforcement, while new firms should pay more attention to enhancing in-house knowledge and skills for IP management.

Second, as indicated in this study, patenting makes new firms more attractive as targets for merger, while it enables new firms to opt for voluntary liquidation as another successful exit strategy. While exit via M\&A is generally the most successful case of cooperative strategies in markets for ideas, its likelihood is increased for new firms by patenting inventions. In addition, new firms can exit via voluntary liquidation as an alternative option in markets for ideas, even if new firms cannot find an appropriate partner for M\&A. From an economic policy perspective, the markets for ideas, especially ones for M\&As of new innovative firms, are not well developed in Japan; they should be further developed to provide entrepreneurs with more incentives 
to expand their businesses, especially high-tech ones. If new firms can conduct research and develop new knowledge more efficiently than large established firms, advancing such a "division of innovative labor" between new and large established firms will promote innovation and productivity growth (Arora et al., 2001).

Third, Japan has faced a low start-up rate (Honjo, 2015) and low economic growth over a long period of time (Fukao \& Kwon, 2006). To achieve economic growth through entrepreneurship, Japanese policymakers have focused on creating more firms. For instance, the Abe administration's growth strategy set a numerical target of a 10\% start-up rate per year in Japan. However, some scholars have criticized this policy direction, arguing that it may promote the entry of low-productivity and non-innovative "revolving door" firms (e.g., Shane, 2009; Branstetter et al., 2014). As shown in this study, new firms acquiring high-quality patents tend to achieve better post-entry performance than other firms (e.g., lower probability of bankruptcy or higher probability of M\&A). To promote sustainable economic growth, policymakers - especially in countries facing economic conditions similar to those in Japan - should shift their attention to the creation of innovative firms (Schneider \& Veugelers, 2010; Colombelli et al., 2016).

\subsection{Limitations and future avenues of research}

This study has some limitations. First, while this study sheds light on the exit routes of new firms, initial public offering (IPO) as entrepreneurial exit is not considered. IPO as well as M\&A is an important option of exit for entrepreneurs (DeTienne \& Cardon, 2012). Especially in Japan, IPO is much more common than M\&A as a successful entrepreneurial exit (Honjo \& Nagaoka, 2018; Honjo, 2020). It may be worthwhile extending the analysis to entrepreneurial exit, including IPO. Second, there may be concerns about the external validity of our findings. For example, this study focused only on newly founded joint-stock companies in Japan and did not include sole proprietorships in the sample. In addition, the institutional context in Japan may differ from that of other countries, which may affect the nature of the exit routes. For example, some scholars show that bankruptcy law in Japan is not entrepreneur-friendly compared to other countries, and it affects the exit intensions of new firms (Peng et al., 2010). Further analysis including sole proprietorships and using data from other countries is warranted.

Future avenues of research are suggested. First, while we focused on the patenting activity of new firms, it would be worthwhile to consider other measures of innovation activities, such as marketing and organizational innovations (e.g., Cefis \& Marsili, 2019). IP other than patents would be important for new firms. For example, acquiring trademarks as a marketing asset may be an important strategy, especially in non-technological sectors such as services industries (e.g., Mendonça et al., 2004; De Vries et al., 2017). Second, while we focused on survival and exit as a measure of postentry performance of firms, it would be worthwhile to use alternative measures, such as growth and profitability (Freel, 2000; Helmers \& Rogers, 2011; Stam \& Wennberg, 2009). Third, the role of patents as intangible assets may change depending on the environment, such as the global financial crisis and COVID-19. Cefis and Marsili (2019) showed that innovation plays a more important role in firm survival, especially in times of crisis. Landini et al. (2020) suggest that intangibles strengthen firms' resilience, i.e., the ability to cope with unexpected shocks. Further analysis taking into account changing environments would enhance our understanding of the role of patenting in firms' survival and exit.

Acknowledgements We thank Orietta Marsili (the handling editor) and other guest editors of this special issue for their insightful comments and suggestions at the Paper Development Workshop (PDW) in Bergamo (May 2019). We also thank two anonymous referees, Elena Cefis, Alex Coad, Marco Grazzi, Sadao Nagaoka, and seminar participants at the PDW, the University of Lille, the Innovation Economics Workshop, and the Tokyo Workshop on Entrepreneurship and Innovation, for their useful comments on earlier versions of this paper.

Funding This study is financially supported by the Grant-in-Aid for Scientific Research (B) (No. 26285060) and the Grant-in-Aid for Scientific Research (C) (No. 18K01639), Japan Society for the Promotion of Science. 


\section{Appendix}

Table 8 Industry distribution of the sample used in this study

\begin{tabular}{|c|c|c|c|c|c|}
\hline \multirow[b]{2}{*}{ Industry } & \multirow[b]{2}{*}{$N$ of obs. } & \multirow[b]{2}{*}{$N$ of firms } & \multicolumn{3}{|l|}{$N$ of exits } \\
\hline & & & Bankruptcy & Merger & Voluntary liquidation \\
\hline Food, beverage, and feed & 2952 & 528 & 25 & 14 & 23 \\
\hline Textiles & 212 & 39 & 0 & 2 & 1 \\
\hline Apparel & 555 & 101 & 4 & 4 & 4 \\
\hline Lumber and wood products & 458 & 78 & 4 & 4 & 1 \\
\hline Furniture and product & 354 & 64 & 3 & 3 & 2 \\
\hline Pulp, paper, and paper products & 244 & 39 & 0 & 0 & 1 \\
\hline Publishing and printing & 1419 & 249 & 17 & 15 & 7 \\
\hline Chemicals & 701 & 122 & 4 & 11 & 6 \\
\hline Petroleum and coal products & 73 & 12 & 1 & 1 & 1 \\
\hline Rubber products & 194 & 30 & 1 & 0 & 0 \\
\hline Leather, leather products, and fur skins & 163 & 30 & 3 & 0 & 0 \\
\hline Ceramic, stone, and clay products & 807 & 131 & 4 & 7 & 5 \\
\hline Steel and non-ferrous metals & 475 & 80 & 3 & 7 & 2 \\
\hline Fabricated metals & 1916 & 338 & 9 & 7 & 14 \\
\hline General machinery & 3293 & 563 & 27 & 13 & 23 \\
\hline Electrical machinery & 1921 & 320 & 15 & 9 & 19 \\
\hline Transportation machinery & 526 & 89 & 2 & 2 & 4 \\
\hline Precision machinery & 500 & 84 & 8 & 2 & 3 \\
\hline Miscellaneous manufacturing & 2038 & 349 & 13 & 8 & 14 \\
\hline Information services (software) & 12,599 & 2,024 & 74 & 69 & 99 \\
\hline Total & 31,400 & 5,270 & 217 & 178 & 229 \\
\hline
\end{tabular}

Table 9 Estimation results for IV Probit regressions with current sales size

\begin{tabular}{|c|c|c|c|c|c|c|}
\hline \multirow[b]{2}{*}{ Variable } & \multicolumn{2}{|l|}{ Bankruptcy } & \multicolumn{2}{|l|}{ Merger } & \multicolumn{2}{|c|}{ Voluntary liquidation } \\
\hline & (i) Bankruptcy & (ii) Patst_gr & (iii) Merger & (iv) Patst_gr & (v) Voluntary & (vi) Patst_gr \\
\hline \multicolumn{7}{|c|}{ Endogenous variable } \\
\hline \multirow[t]{2}{*}{ Patst_gr } & $-0.520 * * *$ & & $0.465 * * *$ & & $0.288 * * *$ & \\
\hline & $(0.004)$ & & $(0.047)$ & & $(0.031)$ & \\
\hline \multicolumn{7}{|c|}{ Control variable } \\
\hline \multirow[t]{2}{*}{ Pre pat } & $0.181 * *$ & $0.520 * *$ & $-0.171 *$ & $0.520 * *$ & -0.098 & $0.520 * *$ \\
\hline & $(0.080)$ & $(0.242)$ & $(0.100)$ & $(0.242)$ & $(0.060)$ & $(0.242)$ \\
\hline \multirow[t]{2}{*}{ Sales_t } & 0.001 & $0.022 * *$ & 0.081 & $0.022 * *$ & $-0.055^{* * *}$ & $0.022 * *$ \\
\hline & $(0.020)$ & $(0.009)$ & $(0.051)$ & $(0.009)$ & $(0.004)$ & $(0.009)$ \\
\hline \multirow[t]{2}{*}{ Size } & 0.016 & -0.004 & $0.129 * * *$ & -0.005 & $0.045 * * *$ & -0.004 \\
\hline & $(0.070)$ & $(0.030)$ & $(0.011)$ & $(0.030)$ & $(0.003)$ & $(0.030)$ \\
\hline \multirow[t]{2}{*}{ Age firm } & $0.025 * * *$ & $0.024 * *$ & $-0.015^{* * *}$ & $0.024 * *$ & 0.009 & $0.024 * *$ \\
\hline & $(0.002)$ & $(0.010)$ & $(0.000)$ & $(0.010)$ & $(0.010)$ & $(0.010)$ \\
\hline
\end{tabular}


Table 9 (continued)

\begin{tabular}{|c|c|c|c|c|c|c|}
\hline \multirow[b]{2}{*}{ Age_founder } & \multicolumn{2}{|l|}{ Bankruptcy } & \multicolumn{2}{|l|}{ Merger } & \multicolumn{2}{|c|}{ Voluntary liquidation } \\
\hline & $0.006^{*}$ & $0.004 * * *$ & 0.000 & $0.004 * * *$ & $0.006 * *$ & $0.004 * * *$ \\
\hline & $(0.003)$ & $(0.001)$ & $(0.002)$ & $(0.001)$ & $(0.003)$ & $(0.001)$ \\
\hline \multirow[t]{2}{*}{$E d u$} & $-0.062 * * *$ & 0.036 & 0.162 & 0.035 & $0.289 * * *$ & 0.036 \\
\hline & $(0.008)$ & $(0.028)$ & $(0.120)$ & $(0.029)$ & $(0.025)$ & $(0.029)$ \\
\hline \multirow[t]{2}{*}{$E d u \_X$} & $-0.108 * *$ & -0.028 & $0.107 * * *$ & -0.028 & $0.302 * * *$ & -0.028 \\
\hline & $(0.045)$ & $(0.093)$ & $(0.022)$ & $(0.093)$ & $(0.008)$ & $(0.093)$ \\
\hline \multicolumn{7}{|l|}{ Instrumental variable } \\
\hline \multirow[t]{2}{*}{ Appro } & & $0.258 * * *$ & & $0.249 * *$ & & $0.257 * * *$ \\
\hline & & $(0.083)$ & & $(0.098)$ & & $(0.088)$ \\
\hline \multirow[t]{2}{*}{ Tech } & & $0.246^{* * *}$ & & $0.266 * * *$ & & $0.247 * * *$ \\
\hline & & $(0.073)$ & & $(0.100)$ & & $(0.085)$ \\
\hline \multirow[t]{2}{*}{ Constant term } & $-1.740 * * *$ & $-0.754 * *$ & $-2.473 * *$ & $-0.766^{* *}$ & $-2.628 * * *$ & $-0.755^{* *}$ \\
\hline & $(0.450)$ & $(0.318)$ & $(0.993)$ & $(0.308)$ & $(0.001)$ & $(0.310)$ \\
\hline Cohort dummies & Yes & Yes & Yes & Yes & Yes & Yes \\
\hline Number of observations & 27,257 & & 27,257 & & 27,257 & \\
\hline Log pseudolikelihood & -53063.830 & & -52946.929 & & -53058.960 & \\
\hline Wald test of exogeneity (chi2) & $27.07 * * *$ & & $6.51 * *$ & & $21.01 * * *$ & \\
\hline
\end{tabular}

Notes: Robust standard errors are in parentheses. ***, **, and * indicate significance at the $1 \%, 5 \%$, and $10 \%$ levels, respectively

Table 10 Estimation results for IV Probit regressions: a sample restricting the maximum age to 8 years

\begin{tabular}{|c|c|c|c|c|c|c|}
\hline \multirow[b]{2}{*}{ Variable } & \multicolumn{2}{|l|}{ Bankruptcy } & \multicolumn{2}{|l|}{ Merger } & \multicolumn{2}{|c|}{ Voluntary liquidation } \\
\hline & (i) Bankruptcy & (ii) Patst_gr & (iii) Merger & (iv) Patst_gr & (v) Voluntary & (vi) Patst_gr \\
\hline \multicolumn{7}{|c|}{ Endogenous variable } \\
\hline \multirow[t]{2}{*}{ Patst_gr } & $-0.157 * *$ & & $0.526 * * *$ & & $0.263 * * *$ & \\
\hline & $(0.074)$ & & $(0.013)$ & & $(0.010)$ & \\
\hline \multicolumn{7}{|c|}{ Control variable } \\
\hline \multirow{2}{*}{ Pre_pat } & $-0.115 * * *$ & $0.454 * *$ & $-0.197 * *$ & $0.455 * *$ & 0.012 & $0.455 * *$ \\
\hline & $(0.019)$ & $(0.196)$ & $(0.080)$ & $(0.196)$ & $(0.012)$ & $(0.196)$ \\
\hline \multirow[t]{2}{*}{ Size } & 0.057 & 0.010 & $0.141 * * *$ & 0.010 & -0.015 & 0.010 \\
\hline & $(0.050)$ & $(0.028)$ & $(0.016)$ & $(0.028)$ & $(0.017)$ & $(0.028)$ \\
\hline \multirow[t]{2}{*}{ Age_firm } & $0.079 * * *$ & $0.034 * * *$ & $0.014 * *$ & $0.034 * * *$ & $0.043 * * *$ & $0.034 * * *$ \\
\hline & $(0.017)$ & $(0.009)$ & $(0.007)$ & $(0.009)$ & $(0.011)$ & $(0.009)$ \\
\hline \multirow[t]{2}{*}{ Age founder } & 0.005 & $0.004 * * *$ & $-0.001 * * *$ & $0.004 * * *$ & 0.004 & $0.004 * * *$ \\
\hline & $(0.003)$ & $(0.001)$ & $(0.000)$ & $(0.001)$ & $(0.003)$ & $(0.001)$ \\
\hline \multirow[t]{2}{*}{$E d u$} & $-0.142 * * *$ & 0.030 & $0.208 * * *$ & 0.029 & $0.304 * * *$ & 0.029 \\
\hline & $(0.003)$ & $(0.029)$ & $(0.067)$ & $(0.030)$ & $(0.034)$ & $(0.029)$ \\
\hline \multirow[t]{2}{*}{$E d u \_X$} & $-0.194 * * *$ & -0.026 & $0.170 * * *$ & -0.026 & $0.312 * * *$ & -0.026 \\
\hline & $(0.015)$ & $(0.078)$ & $(0.059)$ & $(0.078)$ & $(0.001)$ & $(0.078)$ \\
\hline \multicolumn{7}{|c|}{ Instrumental variable } \\
\hline \multirow[t]{2}{*}{ Appro } & & $0.208 * * *$ & & $0.196 * *$ & & $0.203 * * *$ \\
\hline & & $(0.069)$ & & $(0.079)$ & & $(0.069)$ \\
\hline
\end{tabular}


Table 10 (continued)

\begin{tabular}{|c|c|c|c|c|c|c|}
\hline & Bankruptcy & & Merger & & Voluntary liq & tion \\
\hline \multirow[t]{2}{*}{ Tech } & & $0.191 * * *$ & & $0.217 * * *$ & & $0.203 * * *$ \\
\hline & & $(0.068)$ & & $(0.079)$ & & $(0.063)$ \\
\hline \multirow[t]{2}{*}{ Constant term } & $-2.884 * * *$ & $-0.583 * *$ & $-1.948 * * *$ & $-0.597 * *$ & $-2.815 * * *$ & $-0.590 * *$ \\
\hline & $(0.210)$ & $(0.255)$ & $(0.416)$ & $(0.259)$ & $(0.099)$ & $(0.262)$ \\
\hline Cohort dummies & Yes & Yes & Yes & Yes & Yes & Yes \\
\hline Number of observations & \multicolumn{2}{|l|}{30,293} & \multicolumn{2}{|l|}{30,293} & \multicolumn{2}{|l|}{30,293} \\
\hline Log pseudolikelihood & \multicolumn{2}{|l|}{-56882.582} & \multicolumn{2}{|l|}{-56670.977} & \multicolumn{2}{|l|}{-56956.336} \\
\hline Wald test of exogeneity $\left(\mathrm{chi}^{2}\right)$ & \multicolumn{2}{|l|}{$3.20 *$} & \multicolumn{2}{|l|}{$15.10 * * *$} & \multicolumn{2}{|l|}{$72278.45^{* * *}$} \\
\hline
\end{tabular}

Notes: Robust standard errors are in parentheses. ***,**, and * indicate significance at the $1 \%, 5 \%$, and $10 \%$ levels, respectively

Table 11 Estimation results for IV Probit regressions: a sample dropping firms with Pre pat=1 from the sample

\begin{tabular}{|c|c|c|c|c|c|c|}
\hline \multirow[b]{2}{*}{$\begin{array}{l}\text { Variable } \\
\text { (Endogenous variable) }\end{array}$} & \multicolumn{2}{|l|}{ Bankruptcy } & \multicolumn{2}{|l|}{ Merger } & \multicolumn{2}{|c|}{ Voluntary liquidation } \\
\hline & (i)Bankruptcy & (ii) Patst_gr & (iii) Merger & (iv) Patst_gr & (v) Voluntary & (vi) Patst_gr \\
\hline Patst_gr & $\begin{array}{l}-0.114^{* *} \\
(0.045)\end{array}$ & & $\begin{array}{l}0.552 * * * \\
(0.036)\end{array}$ & & $\begin{array}{l}0.496 * * * \\
(0.038)\end{array}$ & \\
\hline (Control variable) & & & & & & \\
\hline Size & $\begin{array}{l}0.061 \\
(0.046)\end{array}$ & $\begin{array}{l}0.013 \\
(0.029)\end{array}$ & $\begin{array}{l}0.157 * * * \\
(0.013)\end{array}$ & $\begin{array}{l}0.013 \\
(0.029)\end{array}$ & $\begin{array}{l}-0.017 * \\
(0.009)\end{array}$ & $\begin{array}{l}0.013 \\
(0.029)\end{array}$ \\
\hline Age firm & $\begin{array}{l}0.060 * * * \\
(0.011)\end{array}$ & $\begin{array}{l}0.028 * * * \\
(0.005)\end{array}$ & $\begin{array}{l}0.006 \\
(0.004)\end{array}$ & $\begin{array}{l}0.028 * * * \\
(0.005)\end{array}$ & $\begin{array}{l}0.015 * * * \\
(0.002)\end{array}$ & $\begin{array}{l}0.028 * * * \\
(0.005)\end{array}$ \\
\hline Age founder & $\begin{array}{l}0.005 \\
(0.004)\end{array}$ & $\begin{array}{l}0.003 * * \\
(0.001)\end{array}$ & $\begin{array}{l}-0.001^{* * *} \\
(0.000)\end{array}$ & $\begin{array}{l}0.003 * * \\
(0.001)\end{array}$ & $\begin{array}{l}0.003 \\
(0.004)\end{array}$ & $\begin{array}{l}0.003 * * \\
(0.001)\end{array}$ \\
\hline$E d u$ & $\begin{array}{l}-0.170 * * * \\
(0.026)\end{array}$ & $\begin{array}{l}0.029 \\
(0.031)\end{array}$ & $\begin{array}{l}0.264 * * * \\
(0.011)\end{array}$ & $\begin{array}{l}0.028 \\
(0.032)\end{array}$ & $\begin{array}{l}0.302 * * * \\
(0.043)\end{array}$ & $\begin{array}{l}0.028 \\
(0.031)\end{array}$ \\
\hline$E d u \_X$ & $\begin{array}{l}-0.204 * * * \\
(0.007)\end{array}$ & $\begin{array}{l}-0.061 \\
(0.101)\end{array}$ & $\begin{array}{l}0.221 * * * \\
(0.012)\end{array}$ & $\begin{array}{l}-0.061 \\
(0.100)\end{array}$ & $\begin{array}{l}0.316 * * * \\
(0.084)\end{array}$ & $\begin{array}{l}-0.061 \\
(0.100)\end{array}$ \\
\hline (Instrumental variable) & & & & & & \\
\hline Appro & & $\begin{array}{l}0.268 * * * \\
(0.029)\end{array}$ & & $\begin{array}{l}0.259 * * * \\
(0.032)\end{array}$ & & $\begin{array}{l}0.262 * * * \\
(0.025)\end{array}$ \\
\hline Tech & & $\begin{array}{l}0.194 * * * \\
(0.019)\end{array}$ & & $\begin{array}{l}0.222 * * * \\
(0.029)\end{array}$ & & $\begin{array}{l}0.213 * * * \\
(0.009)\end{array}$ \\
\hline Constant term & $\begin{array}{l}-2.854 * * * \\
(0.177)\end{array}$ & $\begin{array}{l}-0.629 * * \\
(0.257)\end{array}$ & $\begin{array}{l}-2.229 * * * \\
(0.023)\end{array}$ & $\begin{array}{l}-0.649 * * \\
(0.254)\end{array}$ & $\begin{array}{l}-2.416^{* * *} \\
(0.458)\end{array}$ & $\begin{array}{l}-0.643 * * \\
(0.266)\end{array}$ \\
\hline Cohort dummies & Yes & Yes & Yes & Yes & Yes & Yes \\
\hline Number of observations & 29,484 & & 29,484 & & 29,484 & \\
\hline Log pseudolikelihood & -49730.704 & & -49461.951 & & -49716.692 & \\
\hline Wald test of exogeneity (chi2) & $10.62 * * *$ & & $445.07 * * *$ & & $26.98 * * *$ & \\
\hline
\end{tabular}

Notes: Robust standard errors are in parentheses. $* * *, * *$, and $*$ indicate significance at the $1 \%, 5 \%$, and $10 \%$ levels, respectively. 
Open Access This article is licensed under a Creative Commons Attribution 4.0 International License, which permits use, sharing, adaptation, distribution and reproduction in any medium or format, as long as you give appropriate credit to the original author(s) and the source, provide a link to the Creative Commons licence, and indicate if changes were made. The images or other third party material in this article are included in the article's Creative Commons licence, unless indicated otherwise in a credit line to the material. If material is not included in the article's Creative Commons licence and your intended use is not permitted by statutory regulation or exceeds the permitted use, you will need to obtain permission directly from the copyright holder. To view a copy of this licence, visit http://creativecommons. org/licenses/by/4.0\%.

\section{References}

Aghion, P., Blundell, R., Griffith, R., Howitt, P., \& Prantl, S. (2009). The effects of entry on incumbent innovation and productivity. Review of Economics and Statistics, 91, 20-32.

Arora, A., Fosfuri, A., \& Gambardella, A. (2001). Markets for Technology: The Economics of Innovation and Corporate Strategy. MIT Press.

Arrow, K. J. (1962). Economic welfare and the allocation of resources for invention. In R. R. Nelson (Ed.), The rate and direction of inventive activity: Economic and social factors (pp. 609-626). Princeton University Press.

Audretsch, D. B. (1991). New-firm survival and the technological regime. Review of Economics and Statistics, 68, 520-526.

Audretsch, D. B. (1995). Innovation, growth and survival. International Journal of Industrial Organization, 13, 441-457.

Audretsch, D. B., \& Mahmood, T. (1991). The hazard rate of new establishments: A first report. Economics Letters, 36, 409-412.

Audretsch, D. B., \& Mahmood, T. (1995). New firm survival: New results using a hazard function. Review of Economics and Statistics, 64, 97-103.

Audretsch, D. B., Bönte, W., \& Mahagaonkar, P. (2012). Financial signaling by innovative nascent ventures: The relevance of patents and prototypes. Research Policy, 41, 14071421.

Balcaen, S., Manigart, S., Buyze, J., \& Ooghe, H. (2012). Firm exit after distress: Differentiating between bankruptcy, voluntary liquidation and M\&A. Small Business Economics, 39, 949-975.

Balconi, M., \& Fontana, R. (2011). Entry and innovation: an analysis of the fabless semiconductor business. Small Business Economics, 37, 87-106.

Barney, J. (1991). Firm resources and sustained competitive advantage. Journal of Management, 17, 99-120.

Bartelsman, E., Scarpetta, S., \& Schivardi, F. (2005). Comparative analysis of firm demographics and survival: Evidence from micro-level sources in OECD countries. Industrial and Corporate Change, 14, 365-391.

Bates, T. (1990). Entrepreneur human capital inputs and small business longevity. Review of Economics and Statistics, 72, 551-559.

Blind, K., Cremers, K., \& Mueller, E. (2009). The influence of strategic patenting on companies' patent portfolios. Research Policy, 38, 428-436.
Block, J. H., Thurik, R., \& Zhou, H. (2013). What turns knowledge into innovative products? The role of entrepreneurship and knowledge spillovers. Journal of Evolutionary Economics, 23, 693-718.

Blonigen, B. A., \& Taylor, C. T. (2000). R\&D activity and acquisitions in high technology industries: Evidence from the US electronics industry. Journal of Industrial Economics, 48, 47-70.

Bos, J. W., \& Stam, E. (2014). Gazelles and industry growth: A study of young high-growth firms in the Netherlands. Industrial and Corporate Change, 23, 145-169.

Branstetter, L., Lima, F., Taylor, L. J., \& Venâncio, A. (2014). Do entry regulations deter entrepreneurship and job creation? Evidence from recent reforms in Portugal. Economic Journal, 124, 805-832.

Breitzman, A., \& Thomas, P. (2002). Using patent citation analysis to target/value M\&A candidates. Research-Technology Management, 45, 28-36.

Brouwer, E., \& Kleinknecht, A. (1999). Innovative output, and a firm's propensity to patent.: An exploration of CIS micro data. Research Policy, 28, 615-624.

Buddelmeyer, H., Jensen, P. H., \& Webster, E. (2010). Innovation and the determinants of company survival. Oxford Economic Papers, 62, 26-85.

Buehler, S., Kaiser, C., \& Jaeger, F. (2006). Merge or fail? The determinants of mergers and bankruptcies in Switzerland, 1995-2000. Economics Letters, 90, 88-95.

Ceccagnoli, M. (2009). Appropriability, preemption, and firm performance. Strategic Management Journal, 30, 81-98.

Cefis, E., \& Marsili, O. (2005). A matter of life and death: Innovation and firm survival. Industrial and Corporate Change, 14, 1167-1192.

Cefis, E., \& Marsili, O. (2006). Survivor: The role of innovation in firms' survival. Research Policy, 35, 626-641.

Cefis, E., \& Marsili, O. (2011). Born to flip. Exit decisions of entrepreneurial firms in high-tech and low-tech industries. Journal of Evolutionary Economics, 21, 473-498.

Cefis, E., \& Marsili, O. (2012). Going, going, gone. Exit forms and the innovative capabilities of firms. Research Policy, 41, 795-807.

Cefis, E., \& Marsili, O. (2019). Good times, bad times: innovation and survival over the business cycle. Industrial and Corporate Change, 28, 565-587.

Cefis, E., \& Orsenigo, L. (2001). The persistence of innovative activities: A cross-countries and cross-sectors comparative analysis. Research Policy, 30, 1139-1158.

Cho, Y., Kirkewoog, S., \& Daim, T. U. (2018). Managing strategic intellectual property assets in the fuzzy front end of new product development process. $R \& D$ Management, 48,354 374.

Coad, A. (2014). Death is not a success: Reflections on business exit. International Small Business Journal, 32, 721-732.

Coad, A. (2018). Firm age: a survey. Journal of Evolutionary Economics, 28, 13-43.

Coad, A., Frankish, J., Roberts, R. G., \& Storey, D. J. (2013). Growth paths and survival chances: An application of Gambler's Ruin theory. Journal of Business Venturing, 28, 615-632.

Cohen, W. M. (2010). Fifty years of empirical studies of innovative activity and performance. In B. H. Hall \& N. Rosenberg 
(Eds.), Handbook of the Economics of Innovation (Vol. 1, pp. 129-213). North-Holland.

Colombelli, A., Krafft, J., \& Quatraro, F. (2013). Properties of knowledge base and firm survival: Evidence from a sample of French manufacturing firms. Technological Forecasting and Social Change, 80, 1469-1483.

Colombelli, A., Krafft, J., \& Vivarelli, M. (2016). To be born is not enough: The key role of innovative start-ups. Small Business Economics, 47, 277-291.

Colombo, M. G., Grilli, L., \& Piva, E. (2006). In search of complementary assets: The determinants of alliance formation of high-tech start-ups. Research Policy, 35, 1166-1199.

Conti, A., Thursby, J., \& Thursby, M. (2013). Patents as signals for startup financing. Journal of Industrial Economics, 61, $592-622$.

Cooper, A. C., Gimeno-Gascon, F. J., \& Woo, C. Y. (1994). Initial human and financial capital as predictors of new venture performance. Journal of Business Venturing, 9, 371-395.

Cotei, C., \& Farhat, J. (2018). The M\&A exit outcomes of new, young firms. Small Business Economics, 50, 545-567.

De Jong, J. P., \& Marsili, O. (2015). Founding a business inspired by close entrepreneurial ties: does it matter for survival? Entrepreneurship Theory and Practice, 39, 1005-1025.

De Vries, G., Pennings, E., Block, J. H., \& Fisch, C. (2017). Trademark or patent? The effects of market concentration, customer type and venture capital financing on start-ups' initial IP applications. Industry and Innovation, 24, 325-345.

DeTienne, D. R., \& Cardon, M. S. (2012). Impact of founder experience on exit intentions. Small Business Economics, $38,351-374$.

Dindaroğlu, B. (2018). Determinants of patent quality in US manufacturing: technological diversity, appropriability, and firm size. Journal of Technology Transfer, 43, 1083-1106.

Dunne, T., Roberts, M. J., \& Samuelson, L. (1988). Patterns of firm entry and exit in U.S. manufacturing industries. RAND Journal of Economics, 19, 495-515.

Esteve-Pérez, S., \& Mañez-Castillejo, J. A. (2008). The resourcebased theory of the firm and firm survival. Small Business Economics, 30, 231-249.

Esteve-Pérez, S., Sanchis-Llopis, A., \& Sanchis-Llopis, J. A. (2010). A competing risks analysis of firms' exit. Empirical Economics, 38, 281-304.

European Patent Office. (2013). Patents for software? European law and practice. European Patent Office.

Evans, D. S. (1987). The relationship between firm growth, size, and age: Estimates for 100 manufacturing industries. Journal of Industrial Economics, 35, 567-581.

Fontana, R., \& Nesta, L. (2009). Product innovation and survival in a high-tech industry. Review of Industrial Organization, 34, 287-306.

Freel, M. S. (2000). Do small innovating firms outperform noninnovators? Small Business Economics, 14, 195-210.

Fukao, K., \& Kwon, H. U. (2006). Why did Japan's TFP growth slow down in the lost decade? An empirical analysis based on firm-level data of manufacturing firms. Japanese Economic Review, 57, 195-228.

Gans, J. S., \& Stern, S. (2003). The product market and the market for "ideas": commercialization strategies for technology entrepreneurs. Research Policy, 32, 333-350.
Geroski, P. A. (1995). What do we know about entry? International Journal of Industrial Organization, 13, 421440.

Goto, A., \& Motohashi, K. (2007). Construction of a Japanese patent database and a first look at Japanese patenting activities. Research Policy, 36, 1431-1442.

Goto, A., \& Nagata, A. (1997). Appropriability and technological opportunities: US-Japan comparison. NISTEP Report, No. 48, National Institute for Science and Technology Policy (NISTEP). (in Japanese)

Graham, S. J., \& Sichelman, T. (2008). Why do start-ups patent. Berkeley Technology Law Journal, 23, 1063-1097.

Griliches, Z., \& Mairesse, J. (1984). Productivity and R\&D at the firm level. In Z. Griliches (Ed.), $R \& D$, Patents and Productivity (pp. 339-374). University of Chicago Press.

Grilli, L., Piva, E., \& Lamastra, C. R. (2010). Firm dissolution in high-tech sectors: An analysis of closure and M\&A. Economics Letters, 109, 14-16.

Gruber, M., MacMillan, I. C., \& Thompson, J. D. (2013). Escaping the prior knowledge corridor: What shapes the number and variety of market opportunities identified before market entry of technology start-ups? Organization Science, 24, 280-300.

Hall, B. H. (1993). The stock market's valuation of R\&D investment during the 1980's. American Economic Review, 83, 259-264.

Hall, B. H. (2019). Is there a role for patents in the financing of new innovative firms? Industrial and Corporate Change, 28, 657-680.

Hall, B. H., \& Ziedonis, R. H. (2001). The patent paradox revisited: an empirical study of patenting in the US semiconductor industry, 1979-1995. RAND Journal of Economics, $32,101-128$.

Hall, B. H., Jaffe, A. B., \& Trajtenberg, M. (2001). The NBER patent citation data file: Lessons, insights and methodological tools, NBER Working Paper No. w8498. National Bureau of Economic Research.

Hall, B. H., Jaffe, A., \& Trajtenberg, M. (2005). Market value and patent citations. RAND Journal of Economics, 36, 16-38.

Harada, N. (2007). Which firms exit and why? An analysis of small firm exits in Japan. Small Business Economics, 29, 401-414.

Harhoff, D., Stahl, K., \& Woywode, M. (1998). Legal form, growth and exit of West German firms - empirical results for manufacturing, construction, trade and service industries. Journal of Industrial Economics, 46, 453-488.

Headd, B. (2003). Redefining business success: Distinguishing between closure and failure. Small Business Economics, 21, 51-61.

Helmers, C., \& Rogers, M. (2010). Innovation and the survival of new firms in the UK. Review of Industrial Organization, 36, 227-248.

Helmers, C., \& Rogers, M. (2011). Does patenting help high-tech start-ups? Research Policy, 40, 1016-1027.

Hoenen, S., Kolympiris, C., Schoenmakers, W., \& Kalaitzandonakes, N. (2014). The diminishing signaling value of patents between early rounds of venture capital financing. Research Policy, 43, 956-989.

Hoenig, D., \& Henkel, J. (2015). Quality signals? The role of patents, alliances, and team experience in venture capital financing. Research Policy, 44, 1049-1064. 
Holgersson, M. (2013). Patent management in entrepreneurial SMEs: A literature review and an empirical study of innovation appropriation, patent propensity, and motives. $R \& D$ Management, 43, 21-36.

Honjo, Y. (2000). Business failure of new firms: An empirical analysis using a multiplicative hazards model. International Journal of Industrial Organization, 18, 557-574.

Honjo, Y. (2015). Why are entrepreneurship levels so low in Japan? Japan and the World Economy, 36, 88-101.

Honjo, Y. (2020). Public or perish? From founding to initial public offering. Review of Managerial Science, forthcoming.

Honjo, Y., \& Kato, M. (2019). Do initial financial conditions determine the exit routes of start-up firms? Journal of Evolutionary Economics, 29, 1119-1147.

Honjo, Y., \& Nagaoka, S. (2018). Initial public offering and financing of biotechnology start-ups: Evidence from Japan. Research Policy, 47, 180-193.

Hoshi, T., Kashyap, A., \& Scharfstein, D. (1991). Corporate structure, liquidity, and investment: Evidence from Japanese industrial groups. Quarterly Journal of Economics, 106, 33-60.

Hottenrott, H., Hall, B. H., \& Czarnitzki, D. (2016). Patents as quality signals? The implications for financing constraints on R\&D. Economics of Innovation and New Technology, 25, 197-217.

Hsu, D. H., \& Ziedonis, R. H. (2008). Patents as quality signals for entrepreneurial ventures. In Academy of Management Proceedings (vol. 2008, no. 1 (pp. 1-6). Briarcliff Manor, NY 10510: Academy of Management.

Hsu, D., \& Ziedonis, R. (2013). Resources as dual sources of advantage: Implications for valuing entrepreneurial-firm patents. Strategic Management Journal, 34, 761-781.

Jensen, P. H., \& Webster, E. (2006). Firm size and the use of intellectual property rights. Economic Record, 82, 44-55.

Kang, J. K., Shivdasani, A., \& Yamada, T. (2000). The effect of bank relations on investment decisions: An investigation of Japanese takeover bids. Journal of Finance, 55, 2197-2218.

Kani, M., \& Motohashi, K. (2011). Does pro-patent policy spur innovation? A case of software industry in Japan. In First International Technology Management Conference (pp. 739-744). IEEE.

Kato, M., \& Honjo, Y. (2015). Entrepreneurial human capital and the survival of new firms in high-and low-tech sectors. Journal of Evolutionary Economics, 25, 925-957.

Kato, M., Okamuro, H., \& Honjo, Y. (2015). Does founders' human capital matter for innovation? Evidence from Japanese start-ups. Journal of Small Business Management, $53,114-128$.

Kim, E. H., \& Schatzberg, J. D. (1987). Voluntary corporate liquidations. Journal of Financial Economics, 19, 311-328.

Kline, P., Petkova, N., Williams, H., \& Zidar, O. (2019). Who profits from patents? rent-sharing at innovative firms. Quarterly Journal of Economics, 134, 1343-1404.

Kubo, K., \& Saito, T. (2012). The effect of mergers on employment and wages: Evidence from Japan. Journal of the Japanese and International Economies, 26, 263-284.

Landini, F., Arrighetti, A., \& Lasagni, A. (2020). Economic crisis and firm exit: do intangibles matter? Industry and Innovation, $27,445-479$.
Lanjouw, J. O., \& Schankerman, M. (2004). Protecting intellectual property rights: Are small firms handicapped? Journal of Law and Economics, 47, 45-74.

Lee, S. H., Peng, M. W., \& Barney, J. B. (2007). Bankruptcy law and entrepreneurship development: A real options perspective. Academy of Management Review, 32, 257-272.

Levesque, D., \& Minniti, M. (2006). The effect of aging on entrepreneurial behavior. Journal of Business Venturing, 21, 177-194.

Levin, R., Klevorick, A., Nelson, R., \& Winter, S. (1984). Survey research on R\&D appropriability and technological opportunity. Unpublished manuscript. Yale University.

Levin, R. C., Klevorick, A. K., Nelson, R. R., Winter, S. G., Gilbert, R., \& Griliches, Z. (1987). Appropriating the returns from industrial research and development. Brookings Papers on Economic Activity, 1987, 783-831.

Levitas, E. F., McFadyen, M. A., \& Loree, D. (2006). Survival and the introduction of new technology: a patent analysis in the integrated circuit industry. Journal of Engineering and Technology Management, 23, 182-201.

Markman, G. D., Espina, M. I., \& Phan, P. H. (2004). Patents as surrogates for inimitable and non-substitutable resources. Journal of Management, 30, 529-544.

Mata, J., \& Portugal, P. (1994). Life duration of new firms. Journal of Industrial Economics, 42, 227-245.

Mata, J., Antunes, A., \& Portugal, P. (2007) Borrowing patterns, bankruptcy and voluntary liquidation. Working Paper, Universidade Nova de Lisboa.

Mehrotra, V., van Schaik, D., Spronk, J., \& Steenbeek, O. (2011). Creditor-focused corporate governance: evidence from mergers and acquisitions in Japan. Journal of Financial and Quantitative Analysis, 46, 1051-1072.

Mendonça, S., Pereira, T. S., \& Godinho, M. M. (2004). Trademarks as an indicator of innovation and industrial change. Research Policy, 33, 1385-1404.

Motohashi, K. (2008). Licensing or not licensing? An empirical analysis of the strategic use of patents by Japanese firms. Research Policy, 37, 1548-1555.

Nagaoka, S. (2009). Reform of patent system in Japan and challenges. In National Research Council (Ed.), 21st Century Innovation Systems for Japan and the United States: Lessons from a Decade of Change: Report of a Symposium (pp. 153-168). The National Academies Press.

Nagaoka, S., Motohashi, K., \& Goto, A. (2010). Patent statistics as an innovation indicator. In B. H. Hall \& N. Rosenberg (Eds.), Handbook of the Economics of Innovation. Vol. 2 (pp. 10831127). North-Holland.

Narin, F., Noma, E., \& Perry, R. (1987). Patents as indicators of corporate technological strength. Research Policy, 16, 143155.

Nelson, R. R., \& Wolff, E. N. (1997). Factors behind crossindustry differences in technical progress. Structural Change and Economic Dynamics, 8, 205-220.

Noel, M., \& Schankerman, M. (2013). Strategic patenting and software innovation. Journal of Industrial Economics, 61, 481-520.

Okamuro, H., Kato, M., \& Honjo, Y. (2011). Determinants of $\mathrm{R} \& \mathrm{D}$ cooperation in Japanese start-ups. Research Policy, 40, 728-738. 
Peng, M. W., Yamakawa, Y., \& Lee, S. H. (2010). Bankruptcy Laws and Entrepreneur-Friendliness. Entrepreneurship Theory and Practice, 34, 517-530.

Ponikvar, N., Kejžar, K. Z., \& Peljhan, D. (2018). The role of financial constraints for alternative firm exit modes. Small Business Economics, 51, 85-103.

Rosenbusch, N., Brinckmann, J., \& Bausch, A. (2011). Is innovation always beneficial? A meta-analysis of the relationship between innovation and performance in SMEs. Journal of Business Venturing, 26, 441-457.

Schary, M. A. (1991). The probability of exit. RAND Journal of Economics, 22, 339-353.

Schneider, C., \& Veugelers, R. (2010). On young highly innovative companies: Why they matter and how (not) to policy support them. Industrial and Corporate Change, 19, 9691007.

Serrano, C. J., \& Ziedonis, R. (2019). How redeployable are patent assets? evidence from failed startups. In Academy of Management Proceedings (Vol. 2019, No. 1 (p. 15631). Briarcliff Manor, NY 10510: Academy of Management.

Shane, S. (2009). Why encouraging more people to become entrepreneurs is bad public policy. Small Business Economics, 33, 141-149.

Small and Medium Enterprise Agency. (2014). 2014 White Paper on Small and Medium Enterprises in Japan. Ministry of Economy, Trade and Industry.

Song, M., Podoynitsyna, K., Van Der Bij, H., \& Halman, J. I. (2008). Success factors in new ventures: A meta-analysis. Journal of Product Innovation Management, 25, 7-27.

Stam, E., \& Wennberg, K. (2009). The roles of R\&D in new firm growth. Small Business Economics, 33, 77-89.

Suzuki, S., \& Wright, R. W. (1985). Financial structure and bankruptcy risk in Japanese companies. Journal of International Business Studies, 16, 97-110.

Teece, D. J. (1986). Profiting from technological innovation: Implications for integration, collaboration, licensing and public policy. Research Policy, 15, 285-305.

Thompson, P. (2005). Selection and firm survival: evidence from the shipbuilding industry, 1825-1914. Review of Economics and Statistics, 87, 26-36.
Thurik, A. R., Stam, E., \& Audretsch, D. B. (2013). The rise of the entrepreneurial economy and the future of dynamic capitalism. Technovation, 33, 302-310.

Trajtenberg, M. (1990). A penny for your quotes: patent citations and the value of innovations. RAND Journal of Economics, 21, 172-187.

U.S. Patent and Trademark Office. (2004). Trilateral Statistical Report 2003 Edition. Jointly produced with European Patent Office and Japan Patent Office.

van Pottelsberghe de la Potterie, B., \& François, D. (2009). The cost factor in patent systems. Journal of Industry, Competition and Trade, 9, 329-355.

Veugelers, R., \& Schneider, C. (2018). Which IP strategies do young highly innovative firms choose? Small Business Economics, 50, 113-129.

Wagner, S., \& Cockburn, I. (2010). Patents and the survival of Internet-related IPOs. Research Policy, 39, 214-228.

Wennberg, K., \& DeTienne, D. R. (2014). What do we really mean when we talk about 'exit'? A critical review of research on entrepreneurial exit. International Small Business Journal, 32, 4-16.

Wennberg, K., Wiklund, J., DeTienne, D. R., \& Cardon, M. S. (2010). Reconceptualizing entrepreneurial exit: Divergent exit routes and their drivers. Journal of Business Venturing, 25, 361-375.

Wennekers, S., \& Thurik, R. (1999). Linking entrepreneurship and economic growth. Small Business Economics, 13, 27-56.

Wernerfelt, B. (1984). A resource-based view of the firm. Strategic Management Journal, 5, 171-180.

Wooldridge, J. M. (2010). Econometric Analysis of Cross Section and Panel Data. MIT Press.

Zhou, H., Sandner, P. G., Martinelli, S. L., \& Block, J. H. (2016). Patents, trademarks, and their complementarity in venture capital funding. Technovation, 47, 14-22.

Publisher's note Springer Nature remains neutral with regard to jurisdictional claims in published maps and institutional affiliations. 